\title{
IMPERSONATING THE LEGISLATURE: STATE ATTORNEYS GENERAL AND PARENS PATRIAE PRODUCT LITIGATION
}

\author{
DONALD G. GIFFORD*
}

\begin{abstract}
The state attorney general has emerged during the past decade as a "super plaintiff" in state parens patriae litigation against manufacturers of cigarettes, automobiles, lead paint, and pharmaceuticals. Attorneys general sue on behalf of their states as the collective plaintiff, seeking reimbursement for the costs of treating or preventing product-caused diseases suffered by individual residents, even though such individual victims would not themselves be able to recover as plaintiffs. More importantly, they seek to supplant the regulatory regimes previously enacted by Congress, the state legislature, or federal agencies with one that reflects their own visions. This Article traces how state litigation against product manufacturers requires both a questionable expansion of the state's standing to sue parens patriae and a dubious utilization of longstanding torts such as public nuisance. The Article then employs the intertwined concepts of justiciability and separation of powers to assess the legitimacy of this new wave of regulatory litigation. Finally, it explores how the symbiotic relationship between state attorneys general and a small number of plaintiffs' law firms distorts both governmental priorities and fiscal policy.
\end{abstract}

* Edward M. Robertson Research Professor of Law, University of Maryland. I very much appreciate the contributions of Richard Boldt, Oscar Gray, Bill Reynolds, Jana Singer, Max Stearns, and Greg Young in reviewing earlier drafts of this Article. I also thank Leslie Harrelson, Gina Kline, Tom Prevas, and Alison Silber for their research and editorial assistance. In particular, Ms. Kline's excellent paper completed for my Fall 2006 Mass Product Torts seminar helped inform me about some of the issues considered in this Article.

I use childhood lead poisoning prevention as an example throughout the Article because of my familiarity with the topic. I chaired the Maryland Lead Poisoning Prevention Commission from 1992 through 1995, when the Maryland General Assembly adopted a comprehensive set of statutes recommended by the Commission. I also have been involved with the adoption of stronger lead poisoning prevention legislation in other states, usually working as a consultant for either the National Paint and Coatings Association (NPCA) or E.I. du Pont de Nemours \& Co. (DuPont). Also, on behalf of either NPCA or DuPont, on a few occasions I have urged public officials to forego parens patriae litigation against manufacturers and instead adopt legislative proposals. The views expressed here are mine alone. For more on this topic, see generally Donald G. Gifford, Judicial Overdose: Public Health Litigation Against Product Manufacturers (forthcoming 2009). 


\section{INTRODUCTION}

"What has happened is that the legislatures . . . have failed," explained John P. Coale, a mass products plaintiffs' attorney, as he justified litigation brought by states and municipalities against the manufacturers of tobacco products and handguns. ${ }^{1}$ He forthrightly stated that it was his intent to bring the gun industry to the table to negotiate a new framework for regulating the manufacture and distribution of firearms in a way that Congress and state legislatures had previously rejected. ${ }^{2}$

In less than a decade, litigation filed against product manufacturers by state attorneys general has changed the structure of product regulation in the United States. Tobacco manufacturers operate under a set of detailed regulations governing many aspects of their operations, including advertising directed toward young people, ${ }^{3}$ which are strikingly similar to proposals previously rejected by Congress. ${ }^{4}$ Federal regulators and state legislators, however, did not devise this regulatory regime. The new regulations resulted when state attorneys general and their partners-a handful of plaintiffs' firms focused on mass products liability lawsuits-brought manufacturers to the bargaining table by filing lawsuits asserting novel substantive claims, such as public nuisance. ${ }^{5}$

Cigarettes and handguns are not isolated examples. Last year, the California Attorney General filed tort claims against domestic automobile manufacturers, seeking to regulate automobile emissions in order

\footnotetext{
${ }^{1}$ See John P. Coale, Castano Group, Panel Three: Government-Sponsored LitigationWhat's Next?, Remarks from the Center for Legal Policy at the Manhattan Institute Conference (June 22, 1999), in Regulation by Litigation: The New Wave of GovernmentSponsored Litigation, at 64 (Ctr. for Legal Policy at the Manhattan Inst. 1999), available at http://www.manhattan-institute.org/pdf/mics1.pdf [hereinafter REGULATION BY LiTIGATION]. Coale continued, "They failed to regulate tobacco and they failed regarding guns. . . . Congress is not doing its job. . . . [L] awyers are taking up the slack." Id.

${ }^{2}$ See Peter B. Boyer, Big Guns, New Yorker, May 17, 1999, at 54 (quoting John Coale). The efforts of Coale and others to regulate the firearms industry through litigation were cut short by Congress's enactment of the Protection of Lawful Commerce in Arms Act. See Pub. L. No. 109-92, 119 Stat. 2095 (2005) (codified at 15 U.S.C.A. §§ 7901-7903 (West Supp. 2007)).

${ }^{3}$ Master Settlement Agreement 10-20 (1998) [hereinafter MSA], available at http:// ag.ca.gov/tobacco/pdf/1msa.pdf.

${ }^{4}$ See Robert L. Rabin \& Stephen D. Sugarman, Regulating Tobacco 184 (2001); Robert L. Rabin, The Tobacco Litigation: A Tentative Assessment, 51 DePaul L. Rev. 331, 338 n.34, 340 (2001).

${ }^{5}$ See, e.g., Texas v. Am. Tobacco Co., 14 F. Supp. 2d 956, 971-74 (E.D. Tex. 1997) (discussing various common law claims by the state against tobacco companies and public relations firms).
} 
to prevent global warming. ${ }^{6}$ In 2001, the Attorney General of West Virginia sued the manufacturer of OxyContin, a drug already highly regulated by the FDA. ${ }^{7}$ The Attorney General claimed that Purdue Pharma, the drug manufacturer, was responsible for crimes committed by those abusing the drug. ${ }^{8}$

Many of us would prefer a world in which fewer people smoked and handguns were less accessible. Yet even Robert B. Reich, former Secretary of Labor under President Clinton, finds the antidemocratic aspects of product regulation through attorney general-initiated litigation to be troubling:

$[\mathrm{T}]$ he biggest problem is that these lawsuits are end runs around the democratic process. We used to be a nation of laws, but this new strategy presents novel means of legislating-within settlement negotiations of large civil lawsuits initiated by the executive branch. This is faux legislation, which sacrifices democracy to the discretion of . . . officials operating in secrecy. ${ }^{9}$

Although it is true that the new regulatory schemes were imposed on the manufacturers of cigarettes and OxyContin through settlement rather than judicial action, the state attorney general often wields disproportionate bargaining power in negotiations arising in parens patriae litigation. A product manufacturer might rationally decide to "roll the dice" in the first several rounds of litigation brought by individual claimants and wait for a pattern of liability or no liability

\footnotetext{
${ }^{6}$ Complaint at 2, California ex rel. Lockyer v. Gen. Motors Corp., No. C06-05755 (N.D. Cal. Sept. 20, 2006). The trial court dismissed the complaint on justiciability grounds, but the state has appealed. See California v. Gen. Motors Corp., No. C06-05755, 2007 U.S. Dist. LEXIS 68547, at *48 (N.D. Cal. Sept. 17, 2007), appeal docketed, No. 07-16908 (9th Cir. Oct. 17, 2007); see also infra notes 232-236 and accompanying text.

${ }^{7}$ See Joseph B. Prater, Comment, West Virginia's Painful Settlement: How the OxyContin Phenomenon and Unconventional Theories of Tort Liability May Make Pharmaceutical Companies Liable for Black Markets, 100 Nw. U. L. Rev. 1409, 1428-29 (2006).

${ }^{8}$ See Complaint at 2, 16-19, 23-26, West Virginia ex rel. McGraw v. Purdue Pharma L.P., No. 01-C-137-S (W. Va. Cir. Ct. June 11, 2001), available at http://www.cmht.com/pdfs/ oxycontin-cmpl.pdf.

${ }^{9}$ Robert B. Reich, Don't Democrats Believe in Democracy?, Wall St. J., Jan. 12, 2000, at A22. Reich reserves his strongest criticism for actions brought by the federal government seeking damages against product manufacturers. See id. According to Reich, then New York Attorney General (and later Governor) Eliot Spitzer had stated that New York's lawsuit against gun manufacturers was a "small dagger" but that "[t]he feds' [was] a meat ax.'” Id.
} 
to emerge. ${ }^{10}$ Few manufacturers, however, are capable and willing to risk trial when the plaintiff is a state (or a consortium of state attorneys general operating in concert) that may collect billions of dollars as a result of harms allegedly suffered by millions of its residents. ${ }^{11}$ The initiation of litigation by a state attorney general against the manufacturer of a mass market product is, in its own right, a far weightier matter than simply the initiation of a more typical civil lawsuit. In and of itself, it represents the exercise of regulatory power.

Not all actions brought by state governments against product manufacturers settle, but the power of the state attorney general remains decisive. Consider the recent litigation brought by the Rhode Island Attorney General against the manufacturers of lead pigment, whom the Attorney General alleged were responsible for creating a public nuisance within the state. ${ }^{12}$ During the preceding decade, state officials had failed abysmally in their efforts to enforce the provisions of Rhode Island's legislatively enacted Lead Poisoning Prevention Act, ${ }^{13}$ which declared that a property owner's failure to prevent leadbased paint hazards constituted a public nuisance. ${ }^{14}$ In 2007, in State $v$. Lead Industries Ass'n (Lead Industries Ass'n III), the Superior Court of Rhode Island accepted the Attorney General's invitation to order manufacturers to eliminate the presence of lead-based paint in older residences-a primary cause of childhood lead poisoning. ${ }^{15}$ The trial court's judgment, later reversed, clearly envisioned a complex regulatory campaign to eliminate or reduce lead-based paint hazards in hundreds of thousands of Rhode Island residences, which would have

${ }^{10}$ See, e.g., Illinois Jury Sides with Merck in a 10th Trial over Painkiller, N.Y. Times, Mar. 28, 2007, at C7 (reporting that the manufacturer won ten of fifteen jury trials).

${ }^{11}$ See In re Rhone-Poulenc Rorer Inc., 51 F.3d 1293, 1298, 1299, 1300 (7th Cir. 1995) (contrasting the "intense pressure to settle" facing an industry in aggregate litigation where a single jury "will hold the fate of an industry in the palm of its hand" with the "decentralized process of multiple trials involving different juries, and different standards of liability, in different jurisdictions . . ...").

${ }^{12}$ See generally State v. Lead Indus. Ass'n (Lead Indus. Ass'n IV), 951 A.2d 428 (R.I. 2008). In April or May of 2001, I completed a single-day consulting assignment related to the Rhode Island litigation on behalf of Dickstein Shapiro LLP, which represented E.I. du Pont de Nemours \& Co., at that time a defendant in the litigation. I also testified in favor of the 2002 amendments strengthening rental property owners' obligations under the Rhode Island Lead Poisoning Prevention Act while retained by Dickstein Shapiro.

${ }^{13}$ Lead Poisoning Prevention Act, R.I. Gen. Laws \$§ 23-24.6-1 to 23-24.6-27 (2001 \& Supp. 2007).

${ }^{14} \mathrm{Id} . \S 23-24.6-23(\mathrm{~d})$.

${ }^{15}$ No. PC 99-5226, 2007 R.I. Super. LEXIS 32, at *289-305 (R.I. Super. Ct. Feb. 26, 2007) (discussing remedial phase of litigation), rev'd, 951 A.2d 428. 
overlapped with the state's legislatively approved regulatory system and, to a significant degree, would have supplanted it. ${ }^{16}$

In the Rhode Island trial court, Judge Michael A. Silverstein acknowledged that the court "lack[ed] the degree of expertise in public health issues that is necessary to properly evaluate any remedial plan." ${ }^{\prime 7} \mathrm{He}$ indicated that the dilemma facing the court was one in which "a court is faced with a polycentric problem that cannot easily be resolved through a traditional courtroom-bound adjudicative process." ${ }^{\prime 8}$ Although Judge Silverstein made these observations to justify the appointment of a special master, they stand as a virtual admission of the inability of the judicial process to address complex public health crises. ${ }^{19}$ Evident throughout the trial court's opinion is what Judge Silverstein perceived as the primary regulatory role to be played by the state attorney general: " $[\mathrm{I}] \mathrm{t}$ is the State's responsibility to design and put forth a remedial plan in the first instance . . .."20 In other words, the state attorney general and his partners, the mass products liability tort lawyers who actually conduct the litigation, were to act as quasi-legislators.

Although in 2008, in State v. Lead Industries Ass'n, the Supreme Court of Rhode Island reversed the trial court's order requiring that the defendant-manufacturers abate the alleged public nuisance resulting from lead pigment, the lessons learned from the trial court pro-

16 See id.

${ }^{17}$ Id. at $* 307$.

${ }^{18}$ Id. at *302 (quoting Hart v. Cmty. Sch. Bd., 383 F. Supp. 699, $766-67$ (E.D.N.Y. 1974)). Judge Silverstein continued, "Any solutions will involve a multitude of choices affecting . . other resources, and each choice will affect other choices. Such manycentered problems call for informal consultations and weighing of complex alternatives . . . ." Id. (quoting Hart, 383 F. Supp. at 766-67).

${ }^{19}$ Of course, for decades federal courts tackled difficult social problems when they found that school systems, prisons, and similar state institutions had been operated in an unconstitutional manner. See Gerald N. Rosenberg, The Hollow Hope: Can Courts Bring About Social Change? 42-46, 305-06 (2d ed. 2008). Even in this arena of constitutionally justified judicial activism, many commentators suggest that the judicial process cannot institute structural reforms. See, e.g., id. at 422 ("U.S. Courts can almost never be effective producers of significant social reform."); Colin S. Diver, The Judge as Political Powerbroker: Superintending Structural Change in Public Institutions, 65 VA. L. REv. 43, 90-105 (1979) (finding judges incapable of managing structural reform cases); Paul J. Mishkin, Federal Courts as State Reformers, 35 WASH. \& LeE L. REv. 949, 965-66, 970-71 (1978) (describing the lack of judicial competence to implement broad bureaucratic reforms). In any event, judicial supervision of repairs and renovations in hundreds of thousands of Rhode Island homes seems to be beyond the scope of even the broadest and most complex constitutionally mandated school desegregation or prison reform cases.

${ }^{20}$ Lead Indus. Ass'n III, 2007 R.I. Super. LEXIS 32, at*307. 
ceedings remain both relevant and important. ${ }^{21}$ Government litigation against pigment manufacturers continues in California and Ohio. ${ }^{22}$ Further, producers of lead pigment are but the latest product manufacturers that states have sought to hold liable for product-caused public health problems. ${ }^{23}$ They are unlikely to be the last. Moreover, the Rhode Island lead pigment litigation was the first time that a trial court had begun to evaluate the appropriate judicial remedy after a jury had concluded that manufacturers should abate conditions that resulted in product-caused health problems. ${ }^{24}$

Both the New Jersey Supreme Court, traditionally one of the most influential and pro-plaintiff courts in the country on issues related to products liability, and the Rhode Island Supreme Court recently noted explicitly the antidemocratic character of executive branch officials and courts seeking to use common law claims to remedy a public health problem previously addressed in a far different and inconsistent manner by the state legislature. ${ }^{25}$ In 2007, in In re Lead Paint Litigation, the New Jersey Supreme Court dismissed multiple actions filed against manufacturers of lead paint and lead pigment by municipalities seeking to hold defendants responsible for financing the costs of lead poisoning prevention efforts. ${ }^{26}$ The court extensively reviewed federal and state legislative efforts to reduce the incidence of childhood lead poisoning and acknowledged that, "under the [New Jersey] Lead Paint Act, responsibility for the costs of abatement rests largely on the property owners. ${ }^{„ 27}$ The court found that the state statute declared lead-based paint contained within residential dwelling units "to be a public nuisance" 28 and found this inconsistent with any attempt to hold a product manufacturer liable for the costs

21951 A.2d at 435.

22 County of Santa Clara v. Atl. Richfield Co., 40 Cal. Rptr. 3d 313, 348 (Cal. Ct. App. 2006). See generally Complaint, State v. Sherwin-Williams Co., No. 07 CV 004587 (Ohio Ct. Com. Pl. Apr. 2, 2007), available at http://www.bricker.com/legalservices/industry/manufacturing/nuisance/danncomplaint.pdf. Sherwin-Williams has since been removed to the U.S. District Court for the Southern District of Ohio. See Notice of Removal at 1, Ohio v. Sherwin-Williams Co., 2:08-CV-00079 (S.D. Ohio Jan. 28, 2008).

${ }^{23}$ See infra notes 51-84 and accompanying text.

${ }^{24}$ Lead Indus. Ass'n III, 2007 R.I. Super. LEXIS 32, at $* 280$.

${ }^{25}$ In re Lead Paint Litig., 924 A.2d 484, 505 (N.J. 2007); Lead Indus. Ass'n IV, 951 A.2d at $457-58$.

${ }^{26} 924$ A.2d at 501 (holding that public nuisance claims do not afford a cause of action against lead paint manufacturers); Lead Indus. Ass'n IV, 951 A.2d at 457-58.

${ }^{27}$ Lead Paint Litig., 924 A.2d at 491-94.

${ }^{28} I d$. at 492 (quoting N.J. Stat. AnN. § 24:14A-5 (West 1997)). 
of abating the same problem. ${ }^{29}$ Similarly, the Rhode Island Supreme Court stated that the state legislature's "statutory schemes . . . . reflect the General Assembly's chosen means of responding to the state's childhood lead poisoning problem."30 The court additionally noted that, "[i]mportantly, the General Assembly has recognized that landlords, who are in control of the lead pigment at the time it becomes hazardous, are responsible for maintaining their premises and ensuring that the premises are lead-safe." ${ }^{1}$ In short, each court acknowledged that it would have been inappropriate for it to impose a regulatory scheme to address the public health problems caused by childhood lead poisoning that was inconsistent with the scheme established by its respective state legislature.

Notwithstanding these important opinions, in an era when few if any regulatory regimes are more important than those regulating massproduced products, the initiation of litigation seeking product regulation by state attorneys general is significant. It is far from obvious that our constitutional framework vests such power in state attorneys general. ${ }^{32}$ There can be no doubt that state attorneys general have the authority to file claims on behalf of their state when the state government suffers a direct loss as a result of a defendant's conduct that violates clearly established statutory or common law norms. ${ }^{33}$ Where the attorneys general sue to supersede a product-regulatory structure already in place, however, they dramatically change the traditional allocation of powers among the three coordinate branches of state government. ${ }^{34}$

Part I of this Article describes the attorney general-sponsored state litigation against the manufacturers of tobacco products and lead pigment. ${ }^{35}$ It begins by examining the settlement agreement ending the tobacco litigation, which imposed an entirely new regulatory framework on tobacco manufacturers-one that went far beyond the ex ante regulatory framework. ${ }^{36}$ Part I then describes the Rhode Island Attorney General's 127-page proposal to the trial court in the Rhode Island paint litigation, which outlined a remedial plan for eliminating

\footnotetext{
${ }^{29} I d$. at 501, 505.

${ }^{30}$ Lead Indus. Ass'n IV, 951 A.2d at 457-58.

${ }^{31} I d$.

${ }^{32}$ See infra notes 244-322 and accompanying text.

${ }^{33}$ See, e.g., R.I. GEN. Laws $§ 42-9-6$ (1996) (granting power to litigate claims on behalf of state actors).

34 See infra notes 244-322 and accompanying text.

35 See infra notes 51-126 and accompanying text.

${ }^{36}$ See infra notes 51-84 and accompanying text.
} 
childhood lead poisoning in the state by judicial decree. ${ }^{37}$ These examples illustrate the ways in which the results of parens patriae litigation against product manufacturers more closely resemble a complex set of statutes and administrative regulations than they do a judgment in a common law torts case. ${ }^{38}$

Part II describes why, regardless of whether parens patriae litigation ends with settlement or a court order, the content of settlement or judgment is functionally determined by the state attorney general. ${ }^{39}$ This reallocation of a primary regulatory role to the state attorney general is one not envisioned by state constitutions: the attorney general assumes a regulatory role traditionally regarded as belonging to the legislature and the administrative agencies it creates for specific regulatory tasks. ${ }^{40}$

Some courts have viewed attempts at regulatory litigation as presenting nonjusticiable matters because any judicial decree resulting from such litigation intrudes on the legislative function and therefore addresses a political question..$^{41}$ Part III concludes that the violation of constitutional boundaries actually fits more closely within a separation of powers doctrinal pigeonhole because the attorney general, sometimes aided by the court's imprimatur, intrudes upon the legislative sphere. ${ }^{42}$

This shifting of power to the state attorney general is even more troubling when the role played by large mass torts plaintiffs' firms as co-counsel or trial counsel is considered. ${ }^{43}$ When the state attorney general initiates public products litigation, neither legislatures nor relevant state agencies evaluate which social problems are most deserving of public attention or regulation. ${ }^{44}$ Nor do they systematically evaluate the fairest and most effective ways to finance government programs to address public health or safety issues. ${ }^{45}$ For example, it is not clear that companies that produced lead-based paint, which was outlawed in 1978, should finance the repair of conditions conducive to childhood lead poisoning, which exist predominantly in housing stock that property owners have allowed to deteriorate during the past

37 See infra notes 85-126 and accompanying text.

38 See infra notes 51-126 and accompanying text.

${ }^{39}$ See infra notes 127-215 and accompanying text.

${ }^{40}$ See infra notes 252-262 and accompanying text.

${ }^{41}$ See infra notes 225-243 and accompanying text.

42 See infra notes 285-322 and accompanying text.

${ }^{43}$ See infra notes 323-342 and accompanying text.

${ }^{44}$ See infra notes 285-322 and accompanying text.

${ }^{45}$ See infra notes 285-322 and accompanying text. 
three decades. ${ }^{46}$ Similarly, it is not obvious that pharmaceutical manufacturers should be held liable for the abuse of OxyContin or the destructive criminal behavior of OxyContin abusers instead of the small number of physicians that routinely and sometimes intentionally overprescribe the drug. ${ }^{47}$ Therefore, Part IV considers the reality that, most often, the power shift is not simply one between two elected branches of government-from the legislature and its authorized administrative agencies to the attorney general as a member of the executive branch. ${ }^{48}$ Instead, public policy decisions regarding which public health and safety crises to address and who should be held financially accountable for these matters have been functionally delegated to a small handful of mass products plaintiffs' lawyers who specialize in litigation brought by states and municipalities against products manufacturers. ${ }^{49}$ Wendell Gauthier, who represented the City of New Orleans in its litigation against gun manufacturers, has been described as a proponent of the notion that the plaintiffs' bar has become "a de facto fourth branch of government."

\section{The New Regulatory Regimes}

\section{A. Regulation by Consent Decree: Tobacco Litigation and the Master Settlement Agreement}

In May 1994, then-Mississippi Attorney General Mike Moore filed an action on behalf of his state against tobacco manufacturers. ${ }^{51}$ The suit claimed millions of dollars of damages that Mississippi had sustained as a result of tobacco-related illnesses..$^{52}$ The state, however, incurred the vast bulk of these damages only indirectly and remotely. ${ }^{53}$ In the first instance, individual residents of the state experienced the harms. ${ }^{54}$ Only later did the state pay their medical bills. ${ }^{55}$ The traditional theories of recovery used by individual smokers were therefore

46 See infra notes 308-318 and accompanying text.

${ }^{47}$ See infra notes 319-342 and accompanying text.

48 See infra notes 323-342 and accompanying text.

${ }^{49}$ See infra notes 323-342 and accompanying text.

${ }^{50}$ Douglas McCollam, Long Shot, Am. LAw., June 1999, at 86.

${ }^{51}$ See generally Complaint, Moore ex rel. State v. Am. Tobacco Co., No. 94-1429 (Miss. Ch. Ct. May 23, 1994), available at http://www.library.ucsf.edu/tobacco/litigation/ms/ 2moore.html.

${ }^{52}$ See generally id.

${ }^{53}$ See generally id.

54 See generally id.

55 See generally id. 
inappropriate. Instead, the complaint asserted that the defendants had caused a more general harm to the state and had profited from that harm. ${ }^{56}$ By using public nuisance and other equitable theories of recovery, the state attempted both to avoid the need to prove specific causation of any individual's illness and to eliminate defenses based upon a smoker's own conduct, such as contributory negligence and assumption of risk. ${ }^{57}$ Within three years of the filing of the Mississippi complaint, at least forty states had filed suits against the tobacco manufacturers. ${ }^{58}$

The superficial motive behind such state actions was financial: to be compensated for funds already spent on tobacco-related illnesses. ${ }^{59}$ The mass plaintiffs' firms were also motivated by a sense of retributive justice when they urged the state attorneys general to sue. ${ }^{60}$ As Ron Motley, one of the lead attorneys in the tobacco litigation, argued, "These gangsters have gotten a free ride for forty years."

The most important goal in filing the state actions, however, was to change the conduct of the tobacco companies, either by imposing an alternative regulatory system through judicial action, bankrupting the companies, or imposing sufficiently severe penalties for tobacco company practices, particularly the practices of advertising to young people and artificially manipulating the nicotine content of cigarettes. ${ }^{62}$ The plaintiffs' lawyers and many of the attorneys general who filed the litigation believed that the political branches had failed to regulate the tobacco industry adequately. ${ }^{63}$ Richard A. Daynard, a law professor who was an early proponent of state litigation against tobacco manufacturers, was an important influence on Moore and others. ${ }^{64}$ Daynard and his colleague Graham E. Kelder, Jr. argued, "The tobacco industry's influence over federal and state legislators makes it enormously difficult, if not impossible, for effective tobacco control

${ }^{56}$ See generally Complaint, supra note 51.

57 See generally id.

${ }^{58}$ Robert L. Rabin, The Tobacco Litigation: A Tentative Assessment, 51 DePaul L. Rev. 331, 338 (2001).

${ }^{59}$ See generally Complaint, supra note 51.

${ }^{60}$ Dan Zegart, Civil Warriors: The Legal Siege on the Tobacco Industry 141 (2000).

${ }^{61} I d$. (quoting Ron Motley).

${ }^{62}$ See Graham E. Kelder, Jr. \& Richard A. Daynard, The Role of Litigation in the Effective Control of the Sale and Use of Tobacco, 8 Stan. L. \& PoL'y Rev. 63, 70-71, 73-80 (1997).

${ }^{63}$ See id. at 66-70.

${ }^{64}$ Frank J. Vandall, The Legal Theory and the Visionaries That Led to the Proposed \$368.5 Billion Tobacco Settlement, 27 Sw. U. L. Rev. 473, 478-80 (1998). 
legislation to be passed at the federal or state level." ${ }^{.65}$ They noted a number of occasions in which Congress had intervened to prevent federal agencies from enacting stronger anti-smoking measures in the years following the release of the 1964 Surgeon General's Report establishing the link between smoking and cancer. ${ }^{66}$ Kelder and Daynard concluded that "tobacco products liability litigation is perhaps the most promising and potentially effective means of controlling the sale and use of tobacco." ${ }^{67}$

The states' tobacco litigation, of course, ultimately settled. ${ }^{68}$ The Master Settlement Agreement (the "MSA") agreed upon by the tobacco companies, the state attorneys general, and their privately retained lawyers represented a comprehensive, new regulatory scheme governing the advertising and promotion of tobacco products, and it included prohibitions on tobacco-brand sponsorships of sporting events, outdoor and transit advertising, the use of cartoon characters in all advertising (e.g., Joe Camel), and youth access to free samples. ${ }^{69}$

Despite allegations of inactivity, Congress, state legislatures, and federal administrative agencies had not ignored tobacco regulation issues in the preceding decades. ${ }^{70}$ To the contrary, commentators in 1996 concluded that, "over the course of the past three decades, Congress has micromanaged the cigarette labeling and advertising issue." ${ }^{, 11}$ What frustrated public health and anti-smoking activists and some attorneys general was that the regulatory schemes adopted by the federal and state legislative branches did not go as far as they would have liked.

Reciting just a few of the ways in which the federal and state governments regulated tobacco products prior to the tobacco litigation helps refute any argument that legislatures and administrative agencies had been inactive in this area. ${ }^{72}$ Shortly after the release of the Surgeon General's report on the dangers of smoking in 1964, the Federal Trade Commission (the "FTC") promulgated strong regulations governing the advertising of tobacco products and mandating strong warning la-

\footnotetext{
${ }^{65}$ Kelder \& Daynard, supra note 62, at 63.

${ }^{66} I d$. at $67-68$.

${ }^{67} \mathrm{Id}$. at 70 .

${ }^{68}$ See generally MSA, supra note 3.

${ }^{69}$ See id. at 10-20.

${ }_{70}$ See infra notes 72-81 and accompanying text.

${ }^{71}$ Lars Noah \& Barbara A. Noah, Nicotine Withdrawal: Assessing the FDA's Effort to Regulate Tobacco Products, 48 Ala. L. Rev. 1, 19 (1996).

72 See infra notes 73-81 and accompanying text.
} 
bels. ${ }^{73}$ Congress responded by superseding these requirements with more modest regulations of its own choosing. ${ }^{74}$ Five years later, Congress enacted the Public Health Cigarette Smoking Act of 1969, which banned all television and radio advertising of cigarettes and mandated that cigarette packages contain more explicit health-warning labels. ${ }^{75}$ The federal government subsequently prohibited smoking in federal buildings except in designated areas, ${ }^{76}$ and on all domestic flights and interstate passenger carriers. ${ }^{77}$ Shortly after the initiation of the tobacco litigation, the Food and Drug Administration (the "FDA") proposed new rules that would have classified tobacco as a drug subject to FDA regulation and further curtailed the tobacco companies' promotion of their products. ${ }^{78}$ States also regulated the use of tobacco products. ${ }^{79}$ For example, the State of New York passed the Clean Indoor Air Act in $1989^{80}$ and the Adolescent Tobacco Use Prevention Act in $1992 .{ }^{81}$

In short, Congress and state legislatures, and the administrative agencies they created, had extensively regulated the promotion and marketing of tobacco products prior to the MSA. ${ }^{82}$ Yet the MSA, negotiated by the state attorneys general and resulting from litigation initiated by them, led to an entirely new regime that often governed the same conduct. ${ }^{83}$ State attorneys general and mass products plaintiffs'

${ }^{73}$ Unfair or Deceptive Advertising and Labeling of Cigarettes in Relation to the Health Hazards of Smoking, 29 Fed. Reg. 8324, 8324-75 (July 2, 1964); see also Noah \& Noah, supra note 71 , at 17 .

${ }^{74}$ See Federal Cigarette Labeling and Advertising Act, Pub. L. No 89-92, 79 Stat. 282 (1965) (codified as amended at 15 U.S.C. $\$ \$ 1331-1337$ (2000)).

${ }^{75}$ See Public Health Cigarette Smoking Act of 1969, Pub. L. No. 91-222, §§ 4, 6,84 Stat. 87, 88, 89 (1970) (codified as amended at 15 U.S.C. $\$ \S ~ 1331-1337$ ).

${ }^{76}$ See 41 C.F.R. § 101-20.105-3 (1990), superseded by Exec. Order No. 13,058, 62 Fed. Reg. 43,451 (Aug. 9, 1997) (codified in relevant part at 41 C.F.R. $\$ \S 102-74.315-.320$ (2008)).

${ }^{77}$ See Act of Dec. 22, 1987, Pub. L. No. 100-202, § 328, 101 Stat. 1329, 1329-382 (interstate flights) (current version at 49 U.S.C. $\$ 41706$ (2000); 49 C.F.R. $§ 374.201$ (2007) (interstate passenger-carrying motor vehicles)).

${ }^{78}$ Regulations Restricting the Sale and Distribution of Cigarettes and Smokeless Tobacco to Protect Children and Adolescents, 61 Fed. Reg. 44,396, 44,397, 44,399 (Aug. 28, 1996).

79 See infra notes $80-81$ and accompanying text.

${ }^{80} 1989$ NY State Clean Indoor Air Act, 1989 N.Y. Laws 2328, 2328-34 (codified as amended at N.Y. Pub. Health Law §§ 1399-n to -x (McKinney 2002 \& Supp. 2008)).

${ }^{81} 1992$ Adolescent Tobacco Use Prevention Act, 1992 N.Y. Laws 4202, 4202-06 (codified as amended at N.Y. Pub. Health LaW $\$ \S 1399$-aa to - $l l$ (McKinney 2002 \& Supp. 2008)).

${ }^{82}$ See supra notes 73-81 and accompanying text.

${ }^{83}$ See supra notes 68-69 and accompanying text. 
attorneys ended up playing the regulatory roles traditionally handled by Congress, state legislatures, the FDA, and the FTC. ${ }^{84}$

\section{B. The Rhode Island Attorney General's Proposed Regulatory Regime for Eliminating Childhood Lead Poisoning}

After their successes in the tobacco litigation, several of the plaintiffs' attorneys who pioneered that effort turned their attention to litigation against manufacturers of lead paint or lead pigment. ${ }^{85}$ The State of Rhode Island led this litigation cycle when it filed a lawsuit against several former manufacturers of lead pigment. ${ }^{86}$ In a July 3, 2002 opinion, in State v. Lead Industries Ass'n, the Superior Court of Rhode Island defined the issue as whether "the cumulative effect of lead pigment in paint and in coatings, found in homes, schools, hospitals, and other public and private buildings throughout the State of Rhode Island [is] the creation of a public nuisance[.]"

Lead-based paint, particularly if poorly maintained or deteriorated, can result in a variety of deleterious effects in young children who are exposed to it, including impaired cognitive function, behavior difficulties, impaired hearing, reduced stature, and, in extreme but now rare cases, even death. ${ }^{88}$ Lead-based paint for use in the interior of residences, however, has not been sold since 1978, when it was banned by federal law. ${ }^{89}$ More than eighty percent of the lead still remaining in residential housing was applied before 1940 and less than four percent was applied after $1960 .{ }^{90}$ Most cases of childhood lead poisoning arise in a small percentage of poorly maintained rental properties. ${ }^{91}$

\footnotetext{
${ }^{84}$ See supra notes 68-69 and accompanying text.

${ }^{85}$ Saundra Torry, Lead Paint Could Be Next Big Legal Target, Wash. Post, June 10, 1999, at A1.

${ }^{86}$ See State v. Lead Indus. Ass'n (Lead Indus. Ass'n I), No. 99-5226, 2001 R.I. Super. LEXIS 37, at*1 (R.I. Super. Ct. Apr. 2, 2001), rev'd, 951 A.2d 428 (R.I. 2008).

${ }^{87}$ State v. Lead Indus. Ass'n (Lead Indus. Ass'n II ), No. 99-5226, 2002 R.I. Super. LEXIS 90, at*6 (R.I. Super. Ct. July 3, 2002), rev'd, 951 A.2d 428.

${ }^{88}$ President's Task Force on Environmental Health Risks and Safety Risks to Children, Eliminating Childhood Lead Poisoning: A Federal Strategy Targeting Lead Paint Hazards 1 (2000) [hereinafter President's Task Force].

${ }^{89}$ See 16 C.F.R. $\$ \S 1303.1(\mathrm{a})-(\mathrm{b}), 1303.4(\mathrm{a})$ (2008) (codifying regulation originally promulgated at 42 Fed. Reg. 44,199 (Sept. 1, 1977) (banning "lead-containing paint" from consumer use as a hazardous product)); see also Lead-Based Paint Poisoning Prevention Act, Pub. L. No. 91-695, § 401, 84 Stat. 2078, 2079 (1971) (codified as amended at 42 U.S.C. $\$ 4831$ (2000)) (banning lead paint in federally funded programs).

${ }^{90}$ President's TAsk Force, supra note 88, at 22 tbl.4.

${ }^{91}$ See, e.g., Christy Plumer, Setting Priorities for Prevention of Childhood Lead Poisoning in the City of Providence, at iv (May 2000) (unpublished masters thesis, Brown University) (on file with Brown University) ("Two percent (2\%) of the residential addresses in the
} 
In February 2006, the jury in the Rhode Island lead pigment litigation found that the defendant-manufacturers "should be ordered to abate the public nuisance." $"$ The trial judge then indicated that it was "the State's responsibility to design and put forth a remedial plan in the first instance . . ."93 On September 14, 2007, the Rhode Island Attorney General submitted to the court an ambitious remedial plan that included twenty-four recommendations. ${ }^{94}$ The proposal acknowledged that it was "impractical" to remove all lead paint from Rhode Island residences and schools, ${ }^{95}$ but it nevertheless called for an effort that would have required lead remediation in more than 250,000 Rhode Island residences and 758 schools and child care centers ${ }^{96}$ at an estimated cost to the defendants, and presumably their insurers, of more than $\$ 2.4$ billion. ${ }^{97}$ More than 10,000 trained and skilled workers would have been required to spend more than 8.013 million "labor days" over a period of several years to carry out the Attorney General's proposed plan. ${ }^{98}$

The Attorney General's proposal explained how the lead remediation was to be accomplished in far greater detail than any set of state statutory or regulatory enactments governing lead poisoning prevention anywhere in the United States. For example, in its discussion of "building component replacement," that is, the removal of doors, windows, and trim, one very lengthy paragraph of the Attorney General's proposal instructed: "Using a garden sprayer or atomizer, lightly mist the component to be removed with water . . . ."99 The proposal con-

city housed $51 \%$ of the children with elevated blood-lead levels . . . and $32 \%$ of the addresses where a child resided in 1998 were addresses with a history of multiple poisonings in 1993-1997. This means that if the City had remediated all the houses where multiple poisonings had occurred, 930 addresses in total, a third of the 1998 poisonings would have been prevented.").

${ }^{92}$ State v. Lead Indus. Ass'n (Lead Indus. Ass'n III), No. PC 99-5226, 2007 R.I. Super. LEXIS 32, at *1 (R.I. Super. Ct. Feb. 26, 2007) (quoting the jury verdict form), rev'd, 951 A.2d 428; see also Charles Forelle, Rhode Island Wins Lead-Paint Suit, Wall ST. J., Feb. 23, 2006, at D7 (reporting the jury verdict).

${ }_{93}$ Lead Indus. Ass'n III, 2007 R.I. Super. LEXIS 32, at*307.

${ }^{94}$ See generally R.I. DeP'T AtT'y Gen., Rhode Island Lead Nuisance Abatement Plan 7 (Sept. 14, 2007) [hereinafter Abatement Plan], reprinted in Rhode Island Defendants to Respond to \$2.4B Abatement Plan by Nov. 15, 16-12 Mealey’s Litig. ReP.: LeAd 5 attachment 1 (Oct. 10, 2007).

${ }^{95} \mathrm{Id}$. at 82.

${ }^{96} I d$. at 8.

${ }^{97} I d$. at 122.

${ }^{98} I d$. at $107,115$.

${ }^{99}$ See Abatement Plan, supra note 94, at 67-68. 
tained scores of pages of instructions at a similar level of specificity. ${ }^{100}$ Unlike judicial decrees on school desegregation or prison reform, these instructions were directed not to public officials but to tens of thousands of private individuals. ${ }^{101}$ Some of the directives appeared to be unrelated to the core objective of abating the public nuisance caused by lead pigment. For example, the Attorney General's plan required that windows replaced as a part of the lead remediation "should carry the Energy Star label." ${ }^{102}$ Although such a choice might reflect a wise decision by an individual consumer, or even an appropriate choice by an administrative agency, it seems somewhat out of place as a judicially mandated remedy addressing childhood lead poisoning. Further, the plan envisioned that changes to the detailed abatement procedures for any of the 240,000 permanent housing units could be "granted on a case by case basis due to unique or compelling needs, e.g., clapboard siding is preferred by the owner instead of vinyl siding." 103

In many other regards, the proposal sounded more like a legislative or administrative agency approach, or even that of a public interest think tank, than one of an attorney general to a court. The plan envisioned "pilot projects" in selected neighborhoods and cities, ${ }^{104}$ studies to determine the extent of lead hazards in other buildings, ${ }^{105}$ and administrative flexibility as the effort moved forward. ${ }^{106}$ Further, the plan would not necessarily have abated the nuisance found to exist by the jury. As the Attorney General admitted, "the actionable lead abatement procedures recommended below are not intended to create an entirely risk-free situation, which is not possible." ${ }^{\text {"107 }}$ Finally, if those living in a residence with lead-based paint hazards refused to leave the premises so that the lead could be removed, the recommendations posited several alternatives. ${ }^{108}$ One was that "the occupant could be ordered to participate in the nuisance abatement program" - that is, an occupant might be forcibly evicted for a period of time. ${ }^{109}$ Another possibility was that "the property could be bypassed completely for abatement." ${ }^{110}$ In

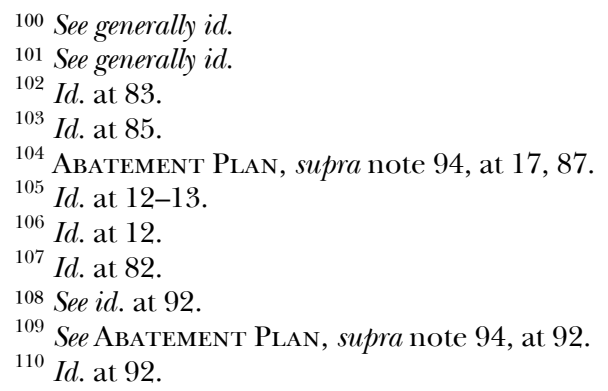


short, the nuisance would not have been abated and the threat to children in the future would have continued to exist.

Obviously, the Attorney General's proposed regulatory scheme for eliminating childhood lead poisoning in Rhode Island has been rendered moot by the Rhode Island Supreme Court's reversal of the trial court's judgment ordering the defendants to abate the public nuisance. ${ }^{111}$ Nevertheless, the plan, considered in the context of the trial court's expressed intent to rely heavily on the Attorney General's recommendations, likely offers a revealing preview of future judicial decrees addressing similar problems. ${ }^{112}$

As was the case with tobacco, the political branches of government had not ignored the public health problems resulting from exposure to lead-based paint. ${ }^{113}$ Since 1978 , a federal statute and regulation have prohibited the manufacture and distribution of residential paint containing lead pigment, the product causing the harm. ${ }^{114}$ Eliminating the risk caused by lead-based paint already covering surfaces of older residential premises, however, has proved to be a far more daunting task. ${ }^{115}$

Consider the Rhode Island Lead Poisoning Prevention Act (the "Act"), which comprises the comprehensive, legislatively enacted regula-

111 See State v. Lead Indus. Ass'n (Lead Indus. Ass'n IV), 951 A.2d 428, 435 (R.I. 2008).

112 See supra notes $92-110$ and accompanying text.

113 See infra notes 114-122 and accompanying text.

${ }^{114}$ See 16 C.F.R. $\$ \S 1303.1$ (a)-(b), 1303.4(a) (2007) (originally promulgated at 42 Fed. Reg. 44,199 (Sept. 1, 1977)) (banning "lead-containing paint" from consumer use as a hazardous product); see also Lead-Based Paint Poisoning Prevention Act, Pub. L. No. 91695, § 401, 84 Stat. 2078, 2079 (1971) (codified as amended at 42 U.S.C. $\$ 4831$ (2000)) (banning lead paint in federally funded programs).

${ }^{115}$ Both federal and state legislation and regulations adopted pursuant to such laws have played a role. For the most part, the role of regulating housing containing lead-based paint, and thus preventing the harm caused in part by the presence of such paint, falls upon the states. See, e.g., MD. Code AnN., Envir. \$§ 6-801 to -852 (LexisNexis 2008); N.Y. Pub. Health Law §§ 1370-a to -e (McKinney 2002); R.I. Gen. Laws §§ 23-24.6-1 to -24.627 (1996 \& Supp. 2006). The complementary federal role is limited to a few narrow and well-circumscribed areas, including regulations governing both federally subsidized housing and safe work practices for those removing lead from residences. See 15 U.S.C. $\S \S 2681-2692$ (2000) (requiring training and certification of contractors working in units containing lead-based paint because the disruption of such paint greatly increases the risk of lead poisoning); 42 U.S.C. $\$ \S 4851-4856$ (2000); 24 C.F.R. $\$ \S 35.100-.175$ (2007); Requirements for Notification, Evaluation and Reduction of Lead-Based Paint Hazards in Federally Owned Residential Property and Housing Receiving Federal Assistance, 64 Fed. Reg. 50,140, 50,142 (Sept. 15, 1999) (codified in scattered sections of 24 C.F.R.) (providing specific requirements of interim control standards-sometimes referred to as "lead safe" standards-for federally owned residential property and housing receiving federal assistance). 
tory scheme in place in Rhode Island. ${ }^{116}$ The legislature declared that the purpose of the Act is to establish "a comprehensive program to reduce exposure to environmental lead and prevent childhood lead poisoning" by "setting standards for eliminating and reducing lead hazards in buildings and premises . . . ."117 Succeeding sections of the Act place responsibility for preventing lead-based paint hazards on the property owner. ${ }^{118}$ These statutes also declare that where the property owner fails to respond to notices of violation from the Department of Health, a residential unit "may be considered . . . a public nuisance." ${ }^{119}$ Further, the Rhode Island statutes specify that property owners need not remove or "abate" all lead from residential premises. ${ }^{120}$ Instead, compliance with a far less rigorous set of requirements known variously as "lead hazard mitigation standard"121 or "lead safe" ${ }^{\text {"22 }}$ suffices.

Thus, the regulatory scheme that the Rhode Island Attorney General sought to implement through his litigation against the manufacturers of lead pigment was dramatically at odds with the one adopted by the state legislature. ${ }^{123}$ The Attorney General assessed the responsibility for addressing lead-based paint hazards on manufacturers of lead pigment, not on property owners. ${ }^{124}$ Further, the attorney generalinitiated litigation resulted in a determination, later reversed, that the presence of lead itself in residential premises throughout the state constituted a public nuisance and that product manufacturers were responsible for abating this nuisance, ${ }^{125}$ a far more demanding standard than the legislature's determination that residential properties should be rendered "lead-safe."126

\section{The Dominant Role of the Attorney General in the New Regulatory Regimes}

If the issue is viewed superficially, a state attorney general clearly possesses the power, under either a state's constitution or its statutes, to initiate claims on behalf of the state's interests and to reach a negotiated

\footnotetext{
${ }^{116}$ R.I. GEN. LAWs $\$ \S 23-24.6-1$ to -24.6-27.

${ }^{117} I d . \S 23-24.6-3$.

118 E.g., id. \$ 23-24.6-17.

${ }^{119} I d . \S 23-24.6-23(\mathrm{~d})$.

${ }^{120}$ Id. $\$ \S 42-128.1-4,-8$.

${ }^{121}$ R.I. GEN. LAWS $§ 42-128.1-4(6)$.

${ }^{122}$ Id. $\S 23-24.6-4(15)$.

123 See supra notes 85-122 and accompanying text.

124 See supra notes 85-122 and accompanying text.

${ }^{125}$ Lead Indus. Ass'n III, 2007 R.I. Super LEXIS 32, at*1.

126 See R.I. GEN. Laws § 23-24.6-4(15).
} 
resolution of the issues in dispute. ${ }^{127}$ The recent filings of claims against product manufacturers, however, are far more than the mere filing of lawsuits. ${ }^{128}$ Regulatory litigation is an attempt on the part of the state attorney general to expand the boundaries of the common law with the explicit purpose of regulating an industry, sometimes leaving defendantmanufacturers with little choice but to acquiesce (through a consent decree) in the attorney general's regulatory scheme. ${ }^{129}$ Thus, attorney general-driven litigation against product manufacturers represents a major shift in regulatory power from the legislative branch and administrative agencies to the attorney general in a manner that could not have been foreseen even fifteen years ago. ${ }^{130}$

This Part examines four factors that have enabled the state attorney general to dominate the regulatory processes which emerge from state litigation against product manufacturers. ${ }^{131}$ It begins with two legal developments during recent decades that grant the attorney general both new authority to litigate on behalf of the state and enormous discretion in identifying targets of regulatory litigation strategies. ${ }^{132}$ First, some courts have dramatically expanded the doctrine of parens patriae to enable states to recover damages or the costs of abatement for harms suffered in the first instance by individual citizens of the states. ${ }^{133}$ Second, and intertwined with the first factor, is the emergence in some jurisdictions of new, vaguely defined causes of action, notably public nuisance, that enable the attorney general to pursue product regulatory litigation even if the individual victims who directly suffered the harms could not themselves successfully sue the manufacturer. ${ }^{134}$ These two developments give the state attorney general, the person who decides whether to file claims on behalf of the state, enormous leeway in selecting product manufacturers as viable litigation targets. ${ }^{135}$

At the other end of the litigation process, in settlement negotiations, the attorney general possesses enormous bargaining leverage resulting from the huge amount of potential liability facing manufacturers as a result of the state's amalgamation of claims of its hundreds of

\footnotetext{
127 See, e.g., id. § 42-9-6 (granting power to litigate claims on behalf of state actors).

128 See infra notes 204-207 and accompanying text.

129 See infra notes 204-207 and accompanying text.

130 See infra notes 204-207 and accompanying text.

131 See infra notes 139-215 and accompanying text.

132 See infra notes 139-203 and accompanying text.

133 See infra notes 139-185 and accompanying text.

134 See infra notes 186-203 and accompanying text.

135 See infra notes 139-203 and accompanying text.
} 
thousands or even millions of residents. ${ }^{136}$ In those instances in which manufacturers bravely decide to "roll the dice" and run the gauntlet of the litigation process instead of settling, certain political realities suggest that the attorney general, more often than not, will retain a dominant role in fashioning the court's remedial decree. ${ }^{137}$ Either of these latter two possibilities combines with the first two factors to allow the attorney general to dominate the mega-regulatory litigation against products manufacturers and, in doing so, to appropriate productregulatory powers traditionally exercised by the legislature and the agencies it creates to regulate products. ${ }^{138}$

\section{A. Expansive Interpretations of the Scope of Parens Patriae Standing}

\section{How Parens Patriae Standing Changes Victim Compensation Within} the Common Law

The attorney general's ability to serve as a collective litigant in products litigation requires that the state government have standing to litigate broadly defined harms experienced by its citizens. ${ }^{139}$ In this so-called parens patriae role, the state asserts that it is entitled to amalgamate the claims of individual victims of product-caused harms and collect damages that, at least initially, were experienced by the individual victims and not by the state itself. ${ }^{140}$ In short, the state becomes a "super plaintiff."

In order for the state to sue product manufacturers in a parens patriae role, that concept must be understood more expansively than it has been in the past. ${ }^{141}$ This loosening of the requirements for parens patriae standing increases the power of state attorneys general and makes their discretionary choices in deciding whether to file such litigation (or to agree to the terms of consent decrees) functionally more similar to the choices made by legislatures and administrative agencies in regulating products than to the attorney general's traditional role as litigator for the state. For example, in the tobacco litigation, states for the first time brought parens patriae actions to recover for harm to the common good that served as a proxy for the amalgamation of individ-

\footnotetext{
136 See infra notes 204-207 and accompanying text.

137 See infra notes 204-207 and accompanying text.

138 See infra notes 204-207 and accompanying text.

139 See infra notes 141-185 and accompanying text.

${ }^{140}$ See infra notes 141-185 and accompanying text.

${ }^{141}$ See infra notes 161-185 and accompanying text.
} 
ual injuries. ${ }^{142}$ These actions sought to protect the states' "quasi-sovereign" interests in the health, safety, and welfare of their citizens. ${ }^{143}$ For the most part, the states' damages consisted of the increased health costs that they sustained through their medical assistance programs. ${ }^{144}$

In parens patriae litigation against product manufacturers, the state nominally asserts that the damages result from damages to the state itself. ${ }^{145}$ Some damages claimed by the state clearly do arise in this manner. ${ }^{146}$ In its action against lead pigment manufacturers, for example, the State of Rhode Island sought to recover its costs in educating its residents about the risks of childhood lead poisoning. ${ }^{147}$ More often, however, as in the tobacco litigation, the damages claimed by the State result largely from injuries initially sustained by its residents, for which the State later assumed financial responsibility through the Medicaid program. ${ }^{148}$

In both the tobacco and lead pigment litigations, the plaintiff-state has served as a conduit for money paid by product manufacturers to be delivered to those directly harmed by the manufacturers' products. ${ }^{149}$ The principal difference between the two situations is that, in the tobacco litigation, the state was reimbursed for money it already had paid to victims of tobacco-related illness. ${ }^{150}$ In the Rhode Island lead pigment litigation, however, the state had not yet expended the funds to abate the nuisance prior to the litigation. ${ }^{151}$ Instead, any expenditure of public funds to eliminate or reduce lead-based paint hazards in Rhode Island residences would not have occurred until the State, or perhaps a special master appointed by the court, received the funds from the defendant-manufacturers or their insurers. ${ }^{152}$

142 See supra notes 51-67 and accompanying text.

${ }^{143}$ See Richard P. Ieyoub \& Theodore Eisenberg, State Attorney General Actions, the Tobacco Litigation, and the Doctrine of Parens Patriae, 74 Tul. L. Rev. 1859, 1865 (2000) (distinguishing quasi-sovereign interests from both proprietary interests and sovereign interests).

144 See supra notes 51-67 and accompanying text.

${ }^{145}$ See, e.g., State v. Lead Indus. Ass'n (Lead Indus. Ass'n I), No. 99-5226, 2001 R.I. Super. LEXIS 37, at*11-12 (R.I. Super. Ct. Apr. 2, 2001), rev'd, 951 A.2d 428 (R.I. 2008) (explaining that in order to maintain a parens patriae action, the state must articulate an interest apart from the interest of particular private parties).

146 See, e.g., id. at *1.

147 See id.

148 See Kelder \& Daynard, supra note 62, at 73.

${ }^{149}$ See infra notes 150-152 and accompanying text.

150 See Kelder \& Daynard, supra note 62, at 73.

151 See State v. Lead Indus. Ass'n (Lead Indus. Ass'n III), No. PC 99-5226, 2007 R.I. Super. LEXIS 32, at *277-316 (R.I. Super. Ct. Feb. 26, 2007) (discussing post-judgment abatement), rev'd, 951 A.2d 428.

152 See id. 
In either instance, the parens patriae litigation enables the private individuals directly harmed-in these examples, the victims of tobaccorelated illness or the owners of property with lead-based paint hazards- to be compensated. It thus accomplishes what the victims themselves could not have accomplished as litigants. The victims of tobaccorelated disease probably could not have recovered because the dangers of cigarette smoking were common knowledge, and they either knew or should have known of these risks. ${ }^{153}$ As the first state attorney general to file a product regulatory action against the tobacco industry noted, however, "[t] he State of Mississippi never smoked a cigarette." ${ }^{154}$ Similarly, Rhode Island property owners almost certainly would not have won in direct actions against the pigment manufacturers because of a host of impediments to recovery, including their inability to identity the specific producers of the lead pigment covering their walls, the longago expiration of the statutes of limitations, and their own failure to use reasonable care to avoid lead-based paint hazards.

Of course, when appropriate, as an alternative to filing parens patriae litigation, the state always can sue as a subrogee of a resident's claims against a manufacturer. ${ }^{155}$ For example, the federal statutes governing the Medicaid program require states to seek reimbursement from any tortfeasors whose actions caused harm to Medicaid recipients that results in medical expenses paid by Medicaid. ${ }^{156}$ As would be expected, the states have enacted subrogation statutes enabling them to sue the tortfeasors in these circumstances. ${ }^{157}$ From the state's perspective, however, the subrogation cause of action poses a problem. As a subrogee, the state "steps into the shoes" of Medicaid recipients and takes their causes of action, subject to any defenses that would be available if the recipients themselves had sued the tortfeasors. ${ }^{158}$ In short, under the subrogation cause of action, the state's claims often would be denied in tobacco litigation because of the smoker's knowledge of the

${ }^{153}$ See Donald G. Gifford, The Challenge to the Individual Causation Requirement in Mass Products Torts, 62 Wash. \& Lee L. Rev. 873, 915-19 (2005).

${ }^{154}$ Mike Moore, The States Are Just Trying to Take Care of Sick Citizens and Protect Children, 83 A.B.A. J. 53, 53 (1997).

155 See infra notes $156-160$ and accompanying text.

156 42 U.S.C. § 1396a(a) (25) (B) (2000).

${ }^{157}$ E.g., Md. Code Ann., Health-Gen. $\$ \S 15-121.1$ to -121.2 (LexisNexis 2008); Tex. Hum. Res. Code ANN. \$ 32.033 (Vernon 2001).

${ }^{158}$ See, e.g., E.H. Ashley \& Co. v. Wells Fargo Alarm Servs., 907 F.2d 1274, 1277 (1st Cir. 1990) (stating that when a subrogee steps into the shoes of a subrogor, the subrogee "has no greater rights against a third party" than did the subrogor). 
risks of smoking. ${ }^{159}$ Similarly, the state's claims would always be denied in actions against lead pigment manufacturers because of the inability to identify the specific manufacturer that produced the product causing an individual victim's harm. ${ }^{160}$ Because these defenses would not preclude recovery if the state is allowed to sue parens patriae, the availability of this form of standing is critical to the state in litigation against product manufacturers.

2. Bending (or Breaking?) the Boundaries of Parens Patriae Standing

Litigation by states against the manufacturers of most types of products extends the parens patriae doctrine far beyond its historical boundaries. The concept of parens patriae is fundamentally a means of granting standing to the state. ${ }^{161}$ Most often, determining whether the state has parens patriae standing to sue a product manufacturer is a question of state law, but state courts frequently are guided by U.S. Supreme Court decisions on parens patriae standing under federal law. ${ }^{162}$

In 1982, in Alfred L. Snapp E Son, Inc. v. Puerto Rico ex rel. Barez, perhaps the Supreme Court's most important parens patriae opinion, the Court considered whether the Commonwealth of Puerto Rico had parens patriae standing in federal courts to represent its "quasi-sovereign" interest in the well-being of its populace. ${ }^{163}$ The Court recognized the right of the Commonwealth (or a state) to sue to protect such quasisovereign interests, as long as it is more than a nominal party and articulates "an interest apart from the interests of particular private parties." 164

In parens patriae litigation against product manufacturers, the state usually satisfies any injury-in-fact test of standing easily, such as when it has sustained financial injury by paying medical assistance payments to victims of tobacco-related illnesses resulting from expo-

159 See id.

160 See id.

161 See Alfred L. Snapp \& Son, Inc. v. Puerto Rico ex rel. Barez, 458 U.S. 592, 607, 609

(1982) (analyzing when a state has standing to sue parens patriae in federal court).

${ }^{162}$ See Ieyoub \& Eisenberg, supra note 143, at 1864.

163458 U.S. at 599. Specifically, Puerto Rico sought to represent the interests of Puerto Rican migrant workers who were being discriminated against in violation of federal law. $I d$. at 597-98. In categorizing Puerto Rico's interests as quasi-sovereign interests, the Court distinguished these interests from "sovereign interests," such as the "the demand for recognition from other sovereigns - most frequently [those] involv[ing] the maintenance and recognition of borders." Id. at 601. The Court also contrasted the government's quasisovereign interests with its proprietary interests-interests similar to those of a private party, such as its ownership of real property or business interests. Id. at 601-02.

${ }^{164} \mathrm{Id}$. at 607 . 
sure to cigarettes. ${ }^{165}$ The state's ability to satisfy the injury-in-fact requirement, however, does not necessarily mean that it should be granted parens patriae standing enabling it to recover damages initially inflicted on other private parties and then passed through to the state. Chief Justice John Roberts recently stated, "Far from being a substitute for Article III injury, parens patriae actions raise an additional hurdle for a state litigant: the articulation of a 'quasi-sovereign interest' 'apart from the interests of particular private parties.',"166

Even though virtually all states filed parens patriae actions against tobacco manufacturers in the late 1990s, many state appellate courts have concluded that a state or municipality does not have standing to sue parens patriae against a product manufacturer because the damages sustained by the government are "derivative" or "too remote."167 For example, in 2001, in Ganim v. Smith $\mathcal{E}$ Wesson Corp., the Connecticut Supreme Court held that the City of Bridgeport lacked parens patriae standing to bring an action against gun manufacturers because the harms allegedly sustained by the city-predominately increased costs for police and other municipal services resulting from the illegal use of guns-were simply too remote from the manufacturers' conduct. $^{168}$

${ }^{165}$ Cf. Massachusetts v. EPA, 127 S. Ct. 1438, 1464-65 (2007) (Roberts, C.J., dissenting) (analyzing the initial requirement for a state to suffer an injury in fact in order to have parens patriae standing under Article III).

${ }^{166} I d$. at 1465 (quoting Snapp, 458 U.S. at 607).

${ }^{167}$ E.g., Ganim v. Smith \& Wesson Corp., 780 A.2d 98, 108 (Conn. 2001) (finding that the City of Bridgeport lacked standing to pursue claims against gun manufacturers); State ex rel. Miller v. Philip Morris, Inc., 577 N.W.2d 401, 406 (Iowa 1998) (holding that the State of Iowa could not sue because its alleged damages were too remote and derivative). Often a functionally identical result is reached, but under a doctrinal pigeonhole other than standing. See, e.g., City \& County of San Francisco v. Philip Morris, Inc., 957 F. Supp. 1130, 1141 (N.D. Cal. 1997) (stating that payment of medical bills by the city and county were too remote as consequences of the actions of tobacco companies to justify recovery under common law of negligence); Dist. of Columbia v. Beretta U.S.A. Corp., 872 A.2d 633, 650 (D.C. 2005) (dismissing a public nuisance claim because of a tenuous causal chain); City of Chicago v. Am. Cyanamid Co., 823 N.E.2d 126, 133 (Ill. App. Ct. 2005) (rejecting the city's claim against a manufacturer of lead pigment because of a lack of proximate causation); Spitzer ex rel. People v. Sturm, Ruger \& Co., 761 N.Y.S.2d 192, 201 (App. Div. 2003) (finding a lack of duty and proximate causation because of a tenuous causal chain).

${ }^{168}$ Ganim, 780 A.2d at 129-30. The court described the causal chain as follows:

The manufacturers sell the handguns to distributors or wholesalers . . . . The distributors then sell the handguns to the retailers . . . . The next set of links is that the retailer then sells the guns either to authorized buyers, namely, legitimate consumers, or, through the "straw man" method or other illegitimate means, to unauthorized buyers, sales that likely would be criminal under federal law. Next, the illegally acquired guns enter an "illegal market." 
In addition to the state and federal cases holding that a state does not have parens patriae standing against a product manufacturer because the state's harms are too remote or derivative, a careful reading of Supreme Court opinions provides a second reason for denying such standing. ${ }^{169}$ The early history of parens patriae, quasi-sovereign interest cases almost entirely consists of disputes between the interests of separate states with regard to natural resources and territory. ${ }^{170}$ For example, in 1906, in Georgia v. Tennessee Copper Co., the United States Supreme Court considered Georgia's request that the Court enjoin a Tennessee manufacturing company from discharging noxious gases over Georgia's territory. ${ }^{171}$ In his classic opinion for the Court, Justice Holmes described the state's quasi-sovereign interests as follows: "In that capacity the State has an interest independent of . . . its citizens, in all the earth and air within its domain. It has the last word as to whether its mountains shall be stripped of their forests and its inhabitants shall breathe pure air." 72 Other Supreme Court decisions recognized the state's ability to sue parens patriae to protect its residents against economic discrimination when such discrimination results from the victims' identities as citizens of the state. ${ }^{173}$ These precedents set the stage for the decision in Snapp in which the Supreme Court held that Puerto Rico has a quasi-sovereign interest in protecting its residents from employment discrimination because "the State has an

From that market, those guns end up in the hands of unauthorized users.

Next, . . . the authorized buyers misuse the guns . . . . [T] he plaintiffs then incur expenses for such municipal necessities as investigation of crime, emergency and medical services for the injured, or similar expenses.

Id. at 123 .

${ }_{169}$ See infra notes 170-179 and accompanying text.

${ }^{170}$ See generally Kansas v. Colorado, 206 U.S. 46 (1907) (holding that Kansas had standing to seek injunctive relief to prohibit Colorado from diverting water from the Arkansas River, an interstate waterway); Missouri v. Illinois, 180 U.S. 208 (1901) (granting Missouri standing to seek an injunction preventing Illinois's discharge of sewage into the Mississippi River).

171206 U.S. 230, 236 (1907).

${ }^{172} I d$. at 237.

${ }^{173}$ E.g., Hawaii v. Standard Oil Co. of Cal., 405 U.S. 251, 258-59 (1972) (recognizing the state's standing to sue in its parens patriae capacity as protector of the economy of the state, but rejecting the state's claim for damages on other grounds); Pennsylvania v. West Virginia, 262 U.S. 553, 591 (1923) (allowing the states of Pennsylvania and Ohio to sue as plaintiffs to protect the quasi-sovereign interests of their citizens when West Virginia's legislature passed a statute requiring all natural gas produced within West Virginia that might be required for local needs be retained within the state); Louisiana v. Texas, 176 U.S. 1, 19 (1900) (recognizing Louisiana's standing to represent the economic interests of its citizens when the state unsuccessfully sought to enjoin a quarantine maintained by Texas officials that limited trade between Texas and the Port of New Orleans). 
interest in securing observance of the terms under which it participates in the federal system." 174

In every one of these precedents, the harms suffered by the original victims were causally connected to their residency within that particular state. ${ }^{175}$ In the environmental cases, the original victims experienced harm because of their physical locations within a state's territory (e.g., noxious gases drifting from Tennessee that harmed individuals and property located within Georgia's boundaries). ${ }^{176}$ In the economic discrimination cases, the economically harmed individuals were harmed because they were citizens of a particular state. ${ }^{177}$ In other words, the victims' harms were directly related and causally connected to their identities as a residents of the states that sought to vindicate their interests through parens patriae litigation. ${ }^{178}$ In public products litigation, however, the state of residence and the harm sustained are independent variables. For example, assuming that the marketplace for tobacco products is nationwide (a seemingly safe assumption), a victim's residence in Iowa neither increases nor decreases that victim's risks of contracting a tobacco-related illness. In other words, the victim's residence in a state is unrelated to the harm suffered. The risk of childhood lead poisoning to the child occupying a dwelling with deteriorated lead-based paint is no greater because that house is located in New York than it would be if the dwelling were located in Illinois. ${ }^{179}$

${ }^{174}$ Snapp, 458 U.S. at $607-08$.

175 See supra notes 170-174 and accompanying text.

176 See Tenn. Copper, 206 U.S. at 237.

177 See supra note 173.

178 See supra note 173.

${ }^{179}$ Admittedly, dicta in the Supreme Court's recent opinion in Massachusetts v. EPA suggest that a state's parens patriae standing might be interpreted broadly enough to encompass a parens patriae action against a product manufacturer:

One helpful indication in determining whether an alleged injury to the health and welfare of its citizens suffices to give the state standing to sue parens patriae is whether the injury is one that the state, if it could, would likely attempt to address through its sovereign lawmaking powers.

127 S. Ct. at 1454 (quoting Snapp, 458 U.S. at 607).

On the surface, the facts in Massachusetts $v$. EPA are remarkably similar to those in mass products liability litigation. See id. at 1446. The alleged injury to Massachusetts is not at all limited to air within its territorial boundaries, but indeed includes the entire earth's atmosphere, making it even more ubiquitous than product-caused mass torts. See id. That said, allowing the state to recover for injury to the physical environment is, of course, consistent with earlier Supreme Court precedents such as Tennessee Copper. See 206 U.S. at 237.

The key distinguishing factor between Massachusetts v. EPA and state-driven products litigation, however, is the Supreme Court's recognition of the importance of the state's 


\section{Parens Patriae and Public Products Litigation}

Allowing the state attorney general to act as a "super plaintiff" and to sue on behalf of the state's residents in actions against products manufacturers turns the fundamental structure of the common law on its head. This approach envisions state social welfare programs, such as Medicaid, as the initial sources of compensation for victims of mass harms caused by product manufacturers. ${ }^{180}$ The state then sues the manufacturers that allegedly caused the mass harms in order to be reimbursed. ${ }^{181}$ In doing so, the state circumvents the inability of many individual victims to recover because they either would not be able to prove the necessary individualized causal connection between a specific manufacturer and a particular plaintiff or because their own conduct would otherwise preclude recovery, or at least reduce it. ${ }^{182}$ This disruption of fundamental common law compensation doctrines ultimately requires an expansive interpretation of the state's standing to sue parens patriae, one that goes far beyond an understanding grounded in U.S. Supreme Court precedents. ${ }^{183}$

Most of the time, the decision of whether the state, acting parens patriae, will decide to sue any particular manufacturer lies solely within the discretion of the state attorney general. ${ }^{184}$ Eliot Spitzer, former Attorney General of New York (and later Governor), has stated that, in

ability, as sovereign within the federal system, to sue the federal government to enforce federal regulatory powers, at least under some circumstances. See 127 S. Ct. at 1454-55. As Justice Stevens stressed in the majority opinion:

When a State enters the Union, it surrenders certain sovereign prerogatives. . . .

These sovereign prerogatives are now lodged in the Federal Government, and Congress has ordered EPA to protect Massachusetts . . . . Congress has moreover recognized a concomitant procedural right to challenge the rejection of its rulemaking petition as arbitrary and capricious. Given that procedural right and Massachusetts' stake in protecting its quasi-sovereign interests, the Commonwealth is entitled to special solicitude in our standing analysis.

Id. at 1454-55 (citations omitted). The state's role in public products litigation obviously is not the unique one present in Massachusetts $v$. EPA, where only the state, as a key partner in the constitutional structure, can protect its interests as a sovereign by enforcing the implementation of powers it has yielded to the federal government. See id.

180 See, e.g., Kelder \& Daynard, supra note 62, at 73.

181 See, e.g., id.

182 See, e.g., id. at 82.

${ }^{183}$ Cf. supra notes 170-174 and accompanying text.

${ }^{184}$ Eliot Spitzer, N.Y. Att'y Gen., Panel One: State Attorneys General and the Power to Change Law, Remarks at the Center for Legal Policy at the Manhattan Institute Conference (June 22, 1999), in Regulation by Litigation, supra note 1, at 21. 
deciding whether to initiate government-sponsored litigation, "[t]he likelihood that [he] would consult the legislature in this process is rather slight." 185 These discretionary decisions of state attorneys general regarding which manufacturing industries to target represent a critical aspect of product regulation in today's economy and a major shift in the allocation of powers among the coordinate branches of government. As analyzed here, the attorney general's new regulatory powers depend, in part, on the slender reed of the state's questionable standing to sue parens patriae.

\section{B. The Indeterminacy of Substantive Claims and the Attorney General's Power}

In mass products liability litigation, state attorneys general utilize substantive tort claims, such as public nuisance, whose boundaries are extremely indeterminate and whose use against product manufacturers is not well grounded historically. ${ }^{186}$ Such vague causes of action enable the state attorney general to wield unprecedented discretion and power in selecting industries to target.

When attorneys general sue product manufacturers, their legal claims typically do not include strict products liability, negligence, implied warranties, or other well-understood products liability theories. To act as the collective plaintiff in public products litigation, the attorney general instead requires innovative substantive tort claims that treat the harm as a harm to society as a whole, instead of as discrete harms to a series of individual victims. These substantive theories of recovery, along with the state's parens patriae role as collective plaintiff, circumvent the traditional requirement of an individualized causal connection between the manufacturer and the victim that often has proved to be insurmountable for victims of latent disease caused by exposure to fungible products. ${ }^{187}$ Further, such a collective approach

\footnotetext{
${ }^{185} \mathrm{Id}$.

186 See infra notes 190-203 and accompanying text.

${ }^{187}$ William Prosser referred to the requirement that victims prove the identity of defendants who caused them harm as "the simplest and most obvious" aspect of determining tort liability. William Prosser, Handbook of the Law of Torts $\S 41$, at 237 (4th ed. 1971). This required proof of individualized causation proved to be particularly cumbersome and annoying obstacles to recovery when an individual victim suffered from a disease caused by product exposure. Donald G. Gifford, The Peculiar Challenges Posed by Latent Diseases Resulting from Mass Production, 64 MD. L. Rev. 613, 653-54 (2005); see, e.g., Bateman v. Johns-Manville Sales Corp., 781 F.2d 1132, 1133 (5th Cir. 1986) (barring recovery in asbestos case where plaintiffs were unable to identify either the specific products causing their diseases or any of the manufacturers of the products); In re "Agent Orange" Prod. Liab. Litig., 611 F. Supp. 1223, 1263 (E.D.N.Y. 1985) (finding that plaintiffs who opted out of
} 
enables the state to recover for the collective harm caused by product exposure, even when individual victims' recoveries would be prevented or reduced by affirmative defenses arising from their own conduct. ${ }^{188}$ Finally, allowing governments or similar entities to sue as collective plaintiffs also makes it more likely that the plaintiff will have access to the resources that individual litigants often lack but that are necessary to take on large corporations. ${ }^{189}$

Beginning with the tobacco litigation, public nuisance emerged as the most important substantive claim in actions brought by states and municipalities seeking damages for collective harm. ${ }^{190}$ By alleging a collective harm, instead of an individual harm, public nuisance claims arguably eliminate any requirement that the state or municipality prove that any specific manufacturer produced the products that caused harm to any specific victim. ${ }^{191}$ Courts in these public nuisance actions

class action settlement were unable to prove that their diseases resulted from exposure to Agent Orange or that "any particular defendant produced the Agent Orange to which he may have been exposed"); Goldman v. Johns-Manville Sales Corp., 514 N.E.2d 691, 702 (Ohio 1987) (same). No one can question the widespread incidence of harms generally attributed to product exposure, such as tobacco-related diseases or childhood lead poisoning, yet it often is difficult or impossible for any individual victim to successfully sue the manufacturer. Gifford, supra note 153, at 877-78; Robert L. Rabin, Essay, A Sociolegal History of the Tobacco Tort Litigation, 44 Stan. L. Rev. 853, 868 (1992); see, e.g., Skipworth v. Lead Indus. Ass'n, Inc., 690 A.2d 169, 175 (Pa. 1997) (affirming dismissal of claims where plaintiff suffering from childhood lead poisoning could not identify specific manufacturers of lead pigment contained in paint that had been applied at various times during a period lasting more than a century to interior walls of house where plaintiff lived).

${ }^{188}$ See Donald G. Gifford, Public Nuisance as a Mass Products Liability Tort, 71 U. Cin. L. REv. 741, 755-56 (2003) (explaining various ways in which courts denied plaintiffs recovery because of their knowledge, actual or attributed, of the dangers of smoking).

${ }^{189}$ See Rabin, supra note 187, at 858-59 (arguing that individual plaintiffs suing the tobacco industry during the 1950s and 1960s were overwhelmed by the superior resources of the industry and buried in pretrial motions and discovery requests).

${ }^{190}$ Until the parens patriae tobacco actions filed in the mid-1990s, public nuisance was typically regarded as "a species of catch-all low-grade criminal offense," William L. Prosser, Private Action for Public Nuisance, 52 VA. L. REv. 997, 999 (1966), or as "the great grab bag, the dust bin, of the law," Award v. McColgan, 98 N.W.2d 571, 573 (Mich. 1959). Public nuisances included environmental harms such as the discharge of untreated sewage, violations of public morals such as playing bingo for money or nude exotic dancing, and even the playing of loud music and anti-abortion protests that blocked access to abortion clinics, but never claims against product manufacturers. See Gifford, supra note 188, at 776 (describing a variety of fact patterns that have resulted in public nuisance claims).

${ }^{191}$ See City of Milwaukee v. NL Indus., Inc., 691 N.W.2d 888, 892 (Wis. Ct. App. 2004) (holding that public nuisance does not require that a causal connection be established between a particular victim and a specific manufacturer); Gifford, supra note 188, at 82628. But see City of St. Louis v. Benjamin Moore \& Co., 226 S.W.3d 110, 116-17 (Mo. 2007) (affirming dismissal of city's claims against paint manufacturers because, even under pub- 
brought by states and municipalities sometimes have described a "public right," the interest protected by the public nuisance tort, more expansively-and less accurately - than its traditional understanding as "an indivisible resource shared by the public at large, like air, water, or public rights of way." 192 Instead, some courts have characterized a statewide or citywide accumulation of private harms as a violation of the entitlement protected by the public nuisance tort. ${ }^{193}$ At least two state appellate courts have held that a manufacturer can be held liable under a public nuisance claim for the sale and distribution of a product. ${ }^{194}$ In 2007 and 2008, however, three state supreme courts reached a contrary conclusion. ${ }^{195}$ Important actions posing the question remain

lic nuisance, plaintiff still must show that a specific defendant caused harm to a particular victim).

${ }^{192}$ Am. Cyanamid, 823 N.E.2d at 131-33 (rejecting the City of Chicago's public nuisance claim).

${ }^{193}$ See Gifford, supra note 188, at 814-19 (discussing interference with a public right). The Wisconsin Court of Appeals accepted this rather dramatic expansion of the public nuisance tort when it allowed the City of Milwaukee to proceed with its public nuisance claims against the manufacturers of lead-based paint and lead pigment. See NL Indus., 691 N.W.2d at 892. That court ignored the failure of the alleged harms to fall within the traditionally recognized boundaries for a public right:

$[\mathrm{T}]$ he City cannot identify the specific lead pigment or paint contained in the houses being abated. The City contends such identification is unnecessary where, as here, it is a community-wide health threat which is the alleged public nuisance . . . . The City maintains that this position is consistent with the fact that public nuisance is focused primarily on harm to the community or the general public, as opposed to individuals who may have suffered specific personal injury or specific property damage. We agree.

$I d$. In the subsequent jury trial, the jury found that although the presence of lead paint in much of the city's housing stock created a public nuisance, the nation's largest manufacturer of lead pigment was not liable because it had not acted negligently. See Marie Rohde, Lead Paint Suit Fails; City Was Seeking \$52.6 Million from Company for Cleanup, MilwaukeE J. Sentinel, June 23, 2007, at B1.

${ }^{194}$ See NL Indus., 691 N.W.2d at 892 (allowing public nuisance claims against manufacturers of lead pigment and lead-based paint); City of Cincinnati v. Beretta U.S.A. Corp., 768 N.E.2d 1136, 1143-44 (Ohio 2002) (allowing public nuisance claims against firearms manufacturers).

195 Benjamin Moore, 226 S.W.3d at 116-17 (affirming dismissal of the city's claims against paint manufacturers because even under public nuisance, a plaintiff still must show that a specific defendant caused harm to a particular victim); In re Lead Paint Litig., 924 A.2d 484, 501-02 (N.J. 2007) (holding that public nuisance claims do not afford a cause of action against product manufacturers); State v. Lead Indus. Ass'n (Lead Indus. Ass'n IV), 951 A.2d 428, 435 (R.I. 2008). 
pending in California and Ohio. ${ }^{196}$ The resolution of this issue may well determine the viability of parens patriae products litigation.

Other substantive claims that are both extremely vague and novel in their recent use by state and local governments against product manufacturers include unjust enrichment ${ }^{197}$ and indemnity. ${ }^{198}$ Even though these claims are common in complaints filed by mass products tort attorneys on behalf of states or municipalities against product manufacturers claiming damages resulting from a product-caused public health or safety crisis, courts almost universally reject such claims in this context. ${ }^{199}$

Still other attorneys general and courts have employed negligence law in an innovative manner to create new claims for negligent distribution or negligent marketing to enable states and municipalities to recover from product manufacturers for the collective harm suffered by members of the public. ${ }^{200}$ These claims are that manufacturers distribute or market their products in an unreasonable manner that foreseeably harms members of the public. ${ }^{201}$ Recovery under

${ }^{196}$ County of Santa Clara v. Atl. Richfield Co., 40 Cal. Rptr. 3d 313, 348 (Ct. App. 2006); Notice of Removal at 1, Ohio v. Sherwin-Williams Co., 2:08-CV-00079 (S.D. Ohio Jan. 28, 2008).

${ }^{197}$ In Rhode Island's action against manufacturers of lead pigment, the trial court initially denied the defendants' motion to dismiss the state's unjust enrichment claim seeking the costs of abating the presence of lead-based paint in the state's thousands of residences. Lead Indus. Ass'n I, 2001 R.I. Super. LEXIS 37, at*50-51; see also NL Indus., 691 N.W.2d at 896-97 (rejecting defendant's motion for summary judgment on restitution claim).

${ }^{198}$ Lead Indus. Ass'n I, 2001 R.I. Super. LEXIS 37, at *51, *53 (concluding that "the state has articulated the requisite elements for an indemnity claim" because "a party who has been exposed to liability solely as a result of the wrongdoing of another should be able to recover from the wrongdoer." (internal quotations omitted)).

${ }^{199}$ See, e.g., Perry v. Am. Tobacco Co., 324 F.3d 845, 857 (6th Cir. 2003) (affirming dismissal of unjust enrichment claims); Or. Laborers-Employers Health \& Welfare Trust Fund v. Phillip Morris, Inc., 185 F.3d 957, 968 (9th Cir. 1999) (same); Steamfitters Local Union No. 420 Welfare Fund v. Phillip Morris, Inc., 171 F.3d 912, 937 (3d Cir. 1999) (same); SEIU Health \& Welfare Fund v. Philip Morris, Inc., 83 F. Supp. 2d 70, 93 (D.D.C. 1999), rev'd on other grounds, 249 F.3d 1068 (D.C. Cir. 2001) (dismissing indemnity claim because plaintiffs had not alleged that they were joint tortfeasors with defendants); Allegheny Gen. Hosp. v. Philip Morris, Inc., 116 F. Supp. 2d 610, 622 (W.D. Pa. 1999), aff'd, 228 F.3d 429 (3d Cir. 2000) (dismissing indemnity claim where plaintiffs were "neither vicariously nor secondarily liable for any torts committed upon their Medicaid, medically indigent or non-paying patients with tobacco-related diseases").

${ }^{200}$ E.g., Cincinnati v. Beretta, 768 N.E.2d at 1145 (reversing dismissal of city's negligence claims against gun manufacturers); see also Prater, supra note 7, at 1430-31 (describing negligent marketing and distribution claims in West Virginia's litigation against manufacturer of OxyContin).

${ }^{201}$ See Richard C. Ausness, Tort Liability for the Sale of Non-Defective Products: An Analysis and Critique of the Concept of Negligent Marketing, 53 S.C. L. Rev. 907, 908 (2002). When employed by public entities, these claims typically targeted gun manufacturers and manufac- 
such claims does not require proof of individualized causal connections between residents first experiencing the harm and specific product manufacturers. ${ }^{202}$ As such, the negligent distribution and marketing claim offers an extremely powerful weapon in the arsenal of the state attorney general. The broadly stated nature of the claim potentially gives the attorney general discretion to file negligent marketing or distribution claims against the manufacturer of virtually any product that causes harm without proof of a product defect or conduct by the manufacturer that was otherwise negligent.

When a state attorney general asks a court to award the state financial recovery, whether "damages" or "the costs of abatement," that attorney general is not asking the court to resolve the case under wellestablished precedent but is asking the court to expand the traditional meanings of common law claims such as public nuisance. ${ }^{203}$ The common law, of course, is a fluid body of law responding to the needs of society. Yet it is disconcerting when a state attorney general, an important official within the executive branch, asks an often popularly elected state court judge to expand the boundaries of an illdefined tort so that the state government itself can recover hundreds of millions or even billions of dollars.

\footnotetext{
turers of OxyContin. See, e.g., Ileto v. Glock, Inc., 349 F.3d 1191, 1197, 1204 (9th Cir. 2003) (reversing the trial court's dismissal of such claims brought by private individuals who had alleged that firearm manufacturers distributed more firearms than the legitimate market could bear and "created an illegal secondary market targeting prohibited purchasers" such as convicted felons); Complaint, supra note 8, at 23. Despite a number of judicial opinions several years ago upholding negligent marketing and distribution claims, more recent decisions tend to reject such a theory of recovery. Compare Hamilton v. Accu-Tek, 62 F. Supp. 2d 802, 829 (E.D.N.Y. 1999) vacated sub nom. Hamilton v. Beretta U.S.A. Corp. 264 F.3d 21 (2d Cir. 2001) (denying defendant-manufacturer's motion for summary judgment with respect to negligent marketing claims), and Merrill v. Navegar, Inc., 89 Cal. Rptr. 2d 146, 189 (Ct. App. 1999), rev'd, 28 P.3d 116 (Cal. 2001) (overturning trial court's grant of summary judgment to manufacturer of semiautomatic assault weapons in claim for negligent marketing), and Cincinnati v. Beretta, 768 N.E.2d at 1145, with Merrill v. Navegar, Inc., 28 P.3d 116, 133 (Cal. 2001), rev'g 89 Cal. Rptr. 2d 146 (Ct. App. 1999) (reversing the lower appellate court's decision and refusing to find negligent marketing), and Hamilton $v$. Beretta, 264 F.3d at 29-32 (rejecting the federal district court's finding of negligent marketing as a source of liability for producers of nondefective products after state court answered certified questions of law).

202 Gifford, supra note 153, at 924-32.

203 See supra notes 187-202 and accompanying text.
} 


\section{The Attorney General's Superior Bargaining Power in Settlement Negotiations}

Defendant-manufacturers, facing potential liability for the amalgamation of tens of thousands or even millions of individual claims if they "roll the dice," most often probably will decide that settlement is a more prudent option. The state's bargaining power is considerably greater, perhaps unconscionably so, as compared with that of any individual litigant in more typical litigation. Judge Richard Posner once contrasted the "intense pressure to settle" facing an industry in aggregate litigation when a single jury "hold[s] the fate of an industry in the palm of its hand" with the "decentralized process of multiple trials, involving different juries, and different standards of liability, in different jurisdictions." ${ }^{204}$ This bargaining leverage is even greater when the product involved has caused widespread health problems affecting millions of people. Further, in the tobacco litigation, more than forty states negotiated as a single block. ${ }^{205}$ The unacceptable risks of "betting the industry" on one or two jury verdicts places the defendant-manufacturers' counsel in an untenable negotiating posture. ${ }^{206}$ At some point in settlement negotiations, an attorney representing a party with a dominant bargaining position more closely resembles a regulator than an attorney or negotiator in more typical settlement negotiations. ${ }^{207}$

\section{The Pragmatism of Judicial Deference to the Attorney General's Regulatory Role}

When the attorney general's parens patriae action against product manufacturers does not settle, but instead extends to trial, one would expect that trial and appellate court judges would provide an effective check on the attorney general's attempt to expand the boundaries of common law torts and to resist the appeal to impose a new regulatory scheme on product manufacturers. Realistically, whether in fact this happens likely depends on whether the trial court and appellate court judges view their judicial roles as "activist" or more restrained; that is,

${ }^{204}$ See In re Rhone-Poulenc Rorer Inc., 51 F.3d 1293, 1298-1300 (7th Cir. 1995).

205 See Rabin, supra note 58, at 338.

${ }^{206}$ See Donald G. Gifford, Legal Negotiation: Theory and Practice 38 (2d ed. 2007) (describing the negotiators' respective alternatives to a negotiated agreement as the most important determinant of bargaining power).

${ }^{207}$ Cf. Donald G. Gifford, Meaningful Reform of Plea Bargaining: The Control of Prosecutorial Discretion, 1983 U. ILL. L. Rev. 37, 54 (analogizing the prosecutor's role in plea bargaining to that of an administrator due to the prosecutor's often overwhelming bargaining power). 
whether their judicial ideologies are more attuned to helping solve social problems or to protect business from what they view as unwarranted legal liabilities and regulation. It is important to remember, however, that in a parens patriae actions against product manufacturers, which allege statewide harms, attorneys general often can "forum shop" to identify trial judges likely to be sympathetic to their causes. To the extent that a national plaintiffs' firm specializing in mass product tort lawsuits selects the state in which to file an initial legal action against a particular industry, it obviously will choose one in which the state supreme court is likely to be favorable.

Even ignoring forum shopping, judges themselves may fail to provide an effective check on the state attorney general. Consider a state supreme court reviewing a trial court's judgment ordering defendantmanufacturers to pay the court or the plaintiff-state hundreds of millions, or even billions, of dollars to address a product-caused public health problem. In a somewhat similar situation, at least one state supreme court justice has openly acknowledged that it was impossible for him to ignore the economic plight of the residents of his own state: "[T]rying unilaterally to make the American tort system more rational . . . will only punish our residents severely . . . ."208 Thus, even if the state's parens patriae action against a product manufacturer is fully litigated and appealed, it is possible that courts would be reluctant to check the attorney general's discretionary choices. This judicial acquiescence obviously augments the attorney general's power.

In short, a state attorney general is far more than an attorney representing a litigant in state litigation against product manufacturers. ${ }^{209}$ Novel interpretations of the scope of the state's parens patriae standing in some jurisdictions allow the attorney general to amalgamate the damages resulting from millions of separate harms suffered directly by residents of the state. ${ }^{210}$ Coupled with expansive reinventions of historically limited causes of action, such as public nuisance, parens patriae standing enables the attorney general to circumvent inabilities to prove causation and affirmative defenses thought to prevent individual victims from recovering in litigation. ${ }^{211}$ Together, these new standing and public nuisance interpretations give the attorney general the power and discretion to sue virtually any manufacturer of

${ }^{208}$ Blankenship v. Gen. Motors Corp., 406 S.E.2d 781, 783, 785 (W. Va. 1991) (Neely, J.) (ruling against a defendant-manufacturer in an automobile crashworthiness case).

209 See supra notes 127-208 and accompanying text.

210 See supra notes 139-185 and accompanying text.

211 See supra notes 186-203 and accompanying text. 
a mass product that repeatedly has caused harm. ${ }^{212}$ At the end of the litigation process, the attorney general possesses overwhelming bargaining power because of the immense scope of damages that otherwise would result from the amalgamation of claims. ${ }^{213}$ If the manufacturers refuse to settle, however, pragmatic realities, at least in many jurisdictions, suggest that the courts may not effectively check the attorney general's attempt to regulate the defendant's industry. ${ }^{214}$ The attorney general has, indeed, become a powerful product regulator. ${ }^{215}$

\section{Justiciability and Separation of Powers}

When an attorney general pursues a detailed regulatory framework to govern an industry, regardless of whether the proposal results in a negotiated consent decree as in the tobacco litigation or in the judicial adoption of the attorney general's recommendations in a judicial decree, that attorney general infringes on the governmental powers constitutionally allocated to the legislature and administrative agencies specifically authorized by the legislature to govern a particular industry. ${ }^{216}$ Of course, merely because a tort judgment has the effect of regulating conduct does not mean that the judicial branch has intruded upon the regulatory prerogatives of the legislature. The regulatory frameworks established by the Master Settlement Agreement (the "MSA") in the tobacco litigation ${ }^{217}$ and by the remedial decree unsuccessfully pursued by the Rhode Island Attorney General in the lead pigment litigation, ${ }^{218}$ however, were entirely different creatures from a mere string of judgments holding a defendant liable for tortious conduct. State attorneys general, powerful officials within the executive branches of their respective states, have consciously intended to regulate industries through detailed regulatory frameworks. ${ }^{219}$ Compensation of victims for their harms has been of secondary consequence.

This realistic appraisal of what happens in the resolution of state parens patriae litigation does not fit neatly into existing constitutional doctrinal pigeonholes governing the allocation of powers among the three coordinate branches of government-the executive, legislative,

212 See supra notes 139-203 and accompanying text.

213 See supra notes 204-207 and accompanying text.

214 See supra note 208 and accompanying text.

215 See supra notes 206-215 and accompanying text.

216 See infra notes 226-284 and accompanying text.

217 See generally MSA, supra note 3.

218 See generally Aваtement Plan, supra note 94.

219 See supra notes 217-218 and accompanying text. 
and judicial. To the extent that judicially devised remedial decrees in state-sponsored mass products liability litigation resemble or even supplant legislative regulation, manufacturers may argue that the remedial issues presented to the courts are nonjusticiable because they represent political questions. ${ }^{220}$ The governmental entity that de facto creates the regulatory framework, however, is not the court, but the attorney general, a member of the executive branch, even when the court ultimately stamps the regulations governing industry with its imprimatur. ${ }^{221}$ If the constitutional issues are viewed through the lens of the attorney general assuming powers that belong to the legislature, then the appropriate doctrinal category becomes separation of powers, a matter closely intertwined with that of justiciability. ${ }^{222}$ In either event, however, the central focus remains the same: the attorney general, a member of the executive branch, sometimes sanctioned by the court, inappropriately has assumed legislative powers.

Section A of this Part explores attorney general-dominated mass products liability litigation as a question of justiciability. ${ }^{223}$ Section B addresses such litigation under a separation of powers analysis. ${ }^{224}$

\section{A. Comprehensive Product Regulatory Decrees and Justiciability}

When state attorneys general file parens patriae actions seeking to impose stronger product or environmental regulation, not surprisingly business interests assert that such actions are political questions that are properly committed to the political branches of government and that, therefore, are nonjusticiable. ${ }^{225}$ The recent regulatory climate, at least at the federal level, has been more pro-business and antiregulatory than at any time in recent memory. The judicial branch appears, to many of those committed to addressing public health problems, to be the last hope for what they perceive to be sound environmental and product regulation.

In deciding whether matters are nonjusticiable because the issues presented pose political questions, courts generally rely heavily on the analytical framework established by the U.S. Supreme Court in 1962 in Baker v. Carr, the seminal political question case:

220 See infra notes 225-243 and accompanying text.

${ }^{221}$ See infra notes 244-284 and accompanying text.

${ }^{222}$ See Baker v. Carr, 369 U.S. 186, 210 (1962) ("The non-justiciability of a political question is primarily a function of the separation of powers.").

223 See infra notes 225-243 and accompanying text.

${ }^{224}$ See infra notes 244-322 and accompanying text.

225 See infra notes 229-237 and accompanying text. 
Prominent on the surface of any case held to involve a political question is found a textually demonstrable constitutional commitment of the issue to a coordinate political department; or a lack of judicially discoverable and manageable standards for resolving it; or the impossibility of deciding without an initial policy determination of a kind clearly for nonjudicial discretion; or the impossibility of a court's undertaking independent resolution without expressing lack of the respect due coordinate branches of government; or an unusual need for unquestioning adherence to a political decision already made; or the potentiality of embarrassment from multifarious pronouncements by various departments on one question. ${ }^{226}$

The Baker Court stated that dismissal of a case on political question grounds may be appropriate even if only one of these factors is "inextricable" from the case. ${ }^{227}$ More recently, a plurality of the Supreme Court described each of these six listed factors as "independent tests."228

In 2005, in Connecticut v. American Electric Power Co., the U.S. District Court for the Southern District of New York dismissed on political question grounds a suit brought by a number of northeastern states against several major power companies alleging that emissions of carbon dioxide into the atmosphere had contributed to the public nuisance of global warming. ${ }^{229}$ The court concluded that, because of the balancing of policy interests necessary to resolve the case, it faced "the impossibility of deciding without an initial policy determination of a kind clearly for nonjudicial discretion." 230 The court also noted the complexity of this initial policy determination. ${ }^{231}$

Similarly, when the Attorney General of California initiated regulatory litigation against automobile manufacturers alleging that they had contributed to the public nuisance of global warming by producing automobiles that emitted carbon dioxide, a federal district court dismissed the complaint because it raised nonjusticiable political ques-

${ }^{226}$ Baker, 369 U.S. at 217; see also Vieth v. Jubelirer, 541 U.S. 267, 277-78 (2004) (plurality opinion) (restating the six independent tests for a political question as established by Baker).

${ }^{227}$ See Baker, 369 U.S. at 217.

${ }^{228}$ Vieth, 541 U.S. at 277.

${ }^{229} 406$ F. Supp. 2d 265, 268 (S.D.N.Y. 2005), appeal argued, No. 05-5104-cv (2d Cir. June 7, 2006).

${ }^{230}$ Id. at 272 (quoting Vieth, 541 U.S. at 278).

231 See id. at 272-73. 
tions. ${ }^{232}$ In California v. General Motors Corp., decided in 2007, the U.S. District Court for the Northern District of California, like the American Electric court, concluded that it would be required to make an initial policy determination, even though the complaint in the California litigation asked for only damages and not equitable relief. ${ }^{233}$ Further, the court reasoned that there were no "judicially discoverable or manageable standards available to resolve" the plaintiff's claim. ${ }^{234}$ The court noted past public nuisance cases in which a state had sought equitable relief from "a source-certain nuisance." ${ }^{235}$ In distinguishing those cases from the case before it, the court stated that it was "left without a manageable method of discerning the entities that are creating and contributing to the alleged nuisance" because there were "multiple worldwide sources of atmospheric warming across myriad industries and multiple countries." 236

In two other recent cases where the government was not the plaintiff, however, federal trial courts rejected the argument that public nuisance actions against product manufacturers were precluded by the political question doctrine. ${ }^{237}$

State parens patriae litigation against product manufacturers, at least when it seeks a complex regulatory regime such as that proposed by the Rhode Island Attorney General in the pigment litigation, appears to raise troubling justiciability issues. Again, I use examples from the Rhode Island pigment litigation, despite the Rhode Island Supreme Court's reversal of the judgment ordering the manufacturers to abate the nuisance. ${ }^{238}$ I do so not to criticize the trial court, but rather to illustrate the justiciability issues that are inherent when courts are asked to grant equitable relief after finding that the mass production of products has resulted in widespread public health problems found to constitute a public nuisance. Because the products have left the manufacturers' possession, the nuisance cannot be abated by a simple judicial order to defendants to abate their conduct. Instead, if widespread public health problems are to be remedied, a massive governmental

\footnotetext{
${ }^{232}$ California v. Gen. Motors Corp., No. C06-05755 MJJ, 2007 U.S. Dist. LEXIS 68547, at $* 48$ (N.D. Cal. Sept. 17, 2007).

${ }^{233} I d$. at $* 22-23$.

${ }^{234} I d$. at $* 43, * 48$ (citing Baker, 369 U.S. at 217).

235 Id. at $* 47$.

${ }^{236} I d$. at $* 47-48$

${ }^{237}$ See In re Methyl Tertiary Butyl Ether ("MTBE”) Prods. Liab. Litig., 438 F. Supp. 2d 291, 304 (S.D.N.Y. 2006); In re "Agent Orange" Prod. Liab. Litig., 373 F. Supp. 2d 7, 64 (E.D.N.Y. 2005).

238 State v. Lead Indus. Ass'n (Lead Indus. Ass'n IV), 951 A.2d 428, 435 (R.I. 2008).
} 
effort is necessary. The question is whether this can be accomplished by a court or whether, instead, such a public health situation requires a response from the legislature and appropriate administrative officers. In short, the myriad of policy decisions necessary to remediate leadbased paint hazards throughout the state may be at the core of the issues that the U.S. Supreme Court regards as political questions.

Looking at the factors identified by the Supreme Court in Baker, there appear to be no "judicially discoverable and manageable standards" that could have justified a decision by the Rhode Island trial court to adopt the Attorney General's 127-page "Rhode Island Nuisance Abatement Plan" governing a multi-year project to eliminate lead-based paint hazards in over 200,000 private residences. ${ }^{239}$ The jury's and trial judge's previous decisions in the case suggest "the impossibility of a court's undertaking independent resolution without expressing lack of the respect due coordinate branches of government." 240 The jury's verdict, upon which the court entered judgment, appears to impose more rigorous standards for the elimination of lead-based paint hazards than those previously enacted by the legislature. ${ }^{241}$ Further, the jury found that lead pigment manufacturers, not property owners, were responsible for abating those hazards. ${ }^{242}$ The Attorney General's lengthy and detailed Abatement Plan, packed with a myriad of decisions arrived at through policy and cost-benefit analyses, suggests that eliminating childhood lead poisoning in Rhode Island is impossible "without an initial policy determination of a kind clearly for non-judicial discretion." 243

\section{B. Attorney General-Sponsored Regulatory Litigation and Separation of Powers}

Viewing complex judicial decrees that attempt to implement solutions to public health problems through the lens of justiciability-that is, determining whether the matter is suitable for judicial resolution or should be left to the legislative branch-risks obscuring the dominant role of the state attorney general in parens patriae litigation against product manufacturers. In litigation against the manufacturers of cigarettes and lead pigment, as well as other products, state attorneys general have taken on for themselves the power to initiate and pursue

239 See Baker, 369 U.S. at 217; supra notes 92-110 and accompanying text.

240 See Baker, 369 U.S. at 217; supra notes 92-93 and accompanying text.

${ }^{241}$ See State v. Lead Indus. Ass'n (Lead Indus. Ass'n III), No. PC 99-256, 2007 R.I. Super. LEXIS 32, at*1 (R.I. Super. Ct. Feb. 26, 2007), rev'd, 951 A.2d 428.

242 See id.

243 See Baker, 369 U.S. at 217; supra notes 94-110 and accompanying text. 
regulatory litigation against product manufacturers. ${ }^{244}$ In doing so, they have expropriated functions traditionally handled in the constitutional framework by the legislative branch and by administrative agencies specifically tasked by the legislature to regulate particular products. ${ }^{245}$ Attorneys general determine whether a manufacturer's conduct impairs the public interest. ${ }^{246}$ They seek regulation of products that is both extensive and detailed, and their actions result in increases in the costs of products, such as cigarettes, which constitute de facto tax increases. ${ }^{247}$ These are functions traditionally allocated to the legislative branch. ${ }^{248}$ Thus, viewed realistically, the conflict in attorney general-initiated product regulatory litigation is not so much between the legislative and the judicial branches as it is between the legislature and the attorney general, a member of the executive branch.

Separation of powers analysis usually concerns the allocation of powers among the coordinate branches of government within a single sovereign, that is, at either the federal or state level. Because the regulation of many products, including cigarettes, is primarily a function of the federal government during the post-New Deal era, ${ }^{249}$ regulatory litigation by state attorneys general raises intertwined issues of separations of powers and federalism, sometimes including questions of federal preemption. ${ }^{250}$ If anything, the assertion of authority by a state attorney general of product-regulatory powers that may be preempted by congressional legislation authorized by the Commerce Clause is doubly upsetting to our constitutional framework. Here, however, I analyze the attorney general's regulatory powers only as a matter of the "horizon-

244 See, e.g., MSA, supra note 3, at 10-20.

245 See infra notes 249-322 and accompanying text.

${ }^{246}$ See Eliot Spitzer, N.Y. Att'y Gen., Panel One: State Attorneys General and the Power to Change Law, at the Center for Legal Policy at the Manhattan Institute Conference (June 22, 1999), in Regulation by Litigation, supra note 1, at 16-21 ("[A]s attorney general, you have to try to define what the public interest is . . . . I do not believe it is appropriate to consult with political bodies before I initiate state litigation.").

247 See, e.g., MSA, supra note 3, at 10-20.

248 See infra notes 308-322 and accompanying text.

${ }^{249}$ See Gary T. Schwartz, Considering the Proper Federal Role in American Tort Law, 38 ARIz. L. REv. 917, 924-32 (1996) (explaining the rationale for federal regulation of the national marketplace); supra notes 70-84 and accompanying text.

${ }^{250}$ See Lorillard Tobacco Co. v. Reilly, 533 U.S. 525, 551 (2001) (finding restrictions on promotion of tobacco products similar to those included in the Master Settlement Agreement to be preempted by the Federal Cigarette Labeling and Advertising Act when imposed by the Massachusetts Attorney General through state regulatory process). 
tal" allocation of powers between the attorney general and the legislature-whether federal or state—and its authorized agencies. ${ }^{251}$

\section{Allocation of Powers and State Governments}

In order to examine the appropriateness of the state attorney general filing public products litigation designed to alter the ex ante product regulatory framework, this Subsection examines the constitutional doctrine generally referred to as "separation of powers." 252 State attorneys general typically are regarded as members of the executive branch of the government, even when they do not answer to their governors and are independently elected. ${ }^{253}$ Strictly speaking, of course, state attorneys general usually are authorized to file suits on behalf of the state. ${ }^{254}$ Because of both the disproportionate power of state attorneys general, particularly when acting collectively, to force a regulatory settlement and the pragmatic political pressures facing state court judges that might otherwise check the attorney general, public products litigation is a classic example of "the 'greatest tyranny,' namely, the 'accumulation of excessive authority in a single branch" "of government. ${ }^{255}$ It also is the assumption of powers traditionally regarded as constitutionally delegated to a coordinate branch

${ }^{251}$ In state attorney general-sponsored litigation against lead pigment manufacturers, the intertwining of separation of powers and federalism issues, although still present, plays a less significant role than it does in the regulation of tobacco products, because most childhood lead poisoning prevention legislation is enacted by the state. See supra note 116 and accompanying text.

${ }^{252}$ I thank Gina Kline for her contributions to this and the next two sections of this Article.

${ }^{253}$ The majority of state constitutions explicitly places the attorney general within the executive branch, and in no state is the attorney general a member of the legislative branch. See, e.g., Utah Const. art. 7, $§ 1$ ("The elective constitutional officers of the Executive Department shall consist of Governor . . . and Attorney General . . . ."). Some scholars, however, characterize the modern attorney general's role as a "quasi-judicial" one, a function that arguably insulates the attorney general from separation of powers concerns. See Henry J. Abraham \& Robert R. Benedetti, The State Attorney General: A Friend of the Court?, 117 U. PA. L. Rev. 795, 797 (1969).

${ }^{254}$ But see McGraw ex rel. State v. Am. Tobacco Co., No. 94-C-1707, 1995 WL 569618, at *2 (W. Va. Cir. Ct. June 6, 1995) (holding that "the Attorney General possesses no common law authority or power" and thus lacked standing to institute or prosecute claims based upon unjust enrichment, public nuisance, fraud, conspiracy, and other common law claims). In McGraw, the court relied on Manchin v. Browning, 296 S.E.2d 909 (W.Va. 1982), which held that the attorney general's ability to act as a plaintiff on behalf of the state is limited to those situations specified in the state constitution or state statutes. McGraw, 1995 WL 569618, at *2 (citing Manchin, 296 S.E.2d at 915-17).

${ }^{255}$ M. Elizabeth Magill, The Real Separation in Separation of Powers Law, 86 VA. L. Rev. 1127, 1149 (2000) (quoting Mistretta v. United States, 488 U.S. 361, 389 (1989)). 
of government, the legislature. Thus, I look at the rich body of separation of powers jurisprudence to guide my analysis of whether the regulatory functions claimed by the state attorney general in public products litigation fit within the constitutional framework. ${ }^{256}$

Separation of powers principles call for the diffusion of power among the legislative, executive, and judicial branches of government. Approximately forty state constitutions explicitly provide that separation of powers principles apply to their state governments. ${ }^{257}$ Even in the absence of such explicit provisions, many scholars find a separation of powers principle implicit within the structure of state government. ${ }^{258}$ Additionally, Laurence Tribe argues that the language of the U.S. Constitution implies that separation of powers principles pertain to the states. ${ }^{259}$ For instance, as Tribe notes, the Guarantee Clause assumes that states will have distinct legislatures and executives. ${ }^{260}$

256 See infra notes 257-307 and accompanying text.

${ }^{257}$ See, e.g., FLA. Const. art. II, $\S 3$ ("No person belonging to one branch shall exercise any powers appertaining to either of the other branches unless expressly provided herein."); ILl. Const. art. II, § 1 ("The legislative, executive and judicial branches are separate. No branch shall exercise powers properly belonging to another."); MAss. Const. pt. 1, art. XXX ("[T] he executive shall never exercise the legislative and judicial powers, or either of them . . . ."); Mich. Const. art. III, $\$ 2$ ("No person exercising powers of one branch shall exercise powers properly belonging to another branch except as expressly provided in this constitution."); N.J. ConsT. art. III, § 1 ("No person or persons belonging to or constituting one branch shall exercise any of the powers properly belonging to either of the others, except as expressly provided in this Constitution."); VA. Const. art. I, $\S 5$ ("That the legislative, executive, and judicial departments of the Commonwealth should be separate and distinct . . . .").

${ }^{258}$ See, e.g., James A. Gardner, Interpreting State Constitutions 161 (2005) ("[E]very state constitution . . . creates a horizontal separation of powers by dividing the power of state government among a legislative, executive, and judicial branch.”); Jim Rossi, Institutional Design and the Lingering Legacy of Antifederalist Separation of Powers Ideals in the States, 52 Vand. L. Rev. 1167, 1190-91 (1999) (finding that the allocation of powers among coordinate branches of government in state constitutions implies that separation of powers principles apply to the states).

259 See, e.g., 1 Laurence Tribe, American Constitutional Law 133-34 (3d ed. 2000) (finding a state separation of powers doctrine implicit in the language of the Guarantee Clause); see also Michael C. Dorf, The Relevance of Federal Norms for State Separation of Powers, 4 Roger Williams U. L. Rev. 51, 54-56, 59 (1998) (arguing that the Guarantee Clause, Article V of the Seventeenth Amendment, and the Supremacy Clause apply separation of powers principles to state governments). But see Sweezy v. New Hampshire, 354 U.S. 234, 255 (1957) (holding that "the concept of separation of powers embodied in the United States Constitution is not mandatory in state governments"); Dreyer v. Illinois, 187 U.S. 71, 84 (1902) ("Whether the legislative, executive, and judicial powers of a State shall be kept altogether distinct and separate . . . is for the determination of the State.").

${ }^{260}$ U.S. Const. art. IV, § 4 ("The United States shall guarantee to every State in this Union a Republican Form of Government, and shall protect each of them against Invasion; and on Application of the Legislature, or of the Executive (when the Legislature 
Even though the separation of powers principle typically applies to both the federal and state governments, there are significant differences between how state constitutions and the U.S. Constitution allocate powers among the coordinate branches of government. Most important, unlike congressional powers, which are limited to the set of enumerated powers listed in the Constitution, the powers of the state legislature are plenary in the absence of constitutional provisions that either limit legislative powers or grant powers to the executive or judicial branch. ${ }^{261}$ In other words, all powers not explicitly allocated to the executive or judicial branch by the state constitution are reserved to the legislature. ${ }^{262}$

\section{Applying Federal Separation of Powers Analysis by Analogy}

State supreme courts seldom have been asked to address separation of powers issues. When they have, they often have borrowed from the U.S. Supreme Court's analysis of the federal separation of powers. ${ }^{263}$ Therefore, this Subsection considers how the separation of powers doctrine, as understood by the U.S. Supreme Court, informs separation of powers analysis at the state level. ${ }^{264}$

Courts and commentators often use the 1952 opinions of Supreme Court Justices Hugo Black and Robert Jackson in Youngstown Sheet $\mathcal{E}^{\circ}$ Tube Co. v. Sawyer to structure separation of powers analysis despite the academic controversy the case has spawned in recent decades. ${ }^{265}$ Con-

cannot be convened) against domestic Violence.”); see Tribe, supra note 259, at 133. In addition, the Seventeenth Amendment refers to both state legislatures and executives. U.S. ConsT. amend. XVII ("When vacancies happen in the representation of any State in the Senate, the executive authority of such State shall issue writs of election to fill such vacancies: Provided, That the legislature of any State may empower the executive thereof to make temporary appointments . . . .").

${ }^{261}$ See G. Alan Tarr, Understanding State Constitutions 16 (1998).

${ }^{262}$ See, e.g., City of Pawtucket v. Sundlun, 662 A.2d 40, 44 (R.I. 1995) (“[T] he General Assembly possesses all powers inherent in the sovereign other than those that the constitution textually commits to the other branches of state government."); Harold H. Bruff, Separation of Powers Under the Texas Constitution, 68 Tex. L. Rev. 1337, 1348 (1990) ("[T]he legislature's power is plenary . . . subject only to limits found in the state or federal constitution.").

263 See TRIBE, supra note 259, at 134.

${ }^{264}$ I am not the first to apply federal separation of powers analysis to similar issues in the state context. See, e.g., id.

${ }^{265}$ See 343 U.S. 579, 582, 634 (1952). Compare Sanford Levinson, The Rhetoric of the Judicial Opinion, in Law's Stories: Narrative and Rhetoric IN THE Law 187, 202 (Peter Brooks \& Paul Gewirtz eds., 1996) (characterizing Justice Jackson's opinion in Youngstown as "the most truly intellectually satisfying . . . opinion in our two-hundred-year constitutional history."), with Jesse Choper, Judicial Review and the National Political 
temporary scholars characterize Justice Black's opinion for the Court as a "formalist" approach to constitutional interpretation because it requires that the exercise of power by any coordinate branch of the government be justified by a firm textual basis in the Constitution. ${ }^{266}$ In Youngstown, the Supreme Court held that President Truman lacked the constitutional power to direct his Secretary of Commerce to seize the nation's steel mills to avert their shutdown as a result of a labor strike during the Korean War. ${ }^{267}$ Justice Black, writing for the majority, found the constitutional analysis remarkably simple: neither any statute nor any provision of the Constitution granted the President such power, either expressly or impliedly. ${ }^{268}$ Notably, Congress previously had rejected the use of plant seizure to prevent labor stoppages. ${ }^{269}$

Under Justice Black's approach, determining whether an attorney general violates separation of powers by initiating regulatory litigation against product manufacturers ultimately depends on how such litigation is interpreted. ${ }^{270}$ If the issue is viewed superficially, the attorney general almost always possesses the power, under either the state constitution or statutes, to initiate claims on behalf of the state's interests. ${ }^{271}$ As previously explained, however, the recent examples of the filings of regulatory litigation are far more than the mere filings of lawsuits. ${ }^{272}$ Regulatory litigation is an attempt on the part of the state attorney general to expand the boundaries of the common law with the explicit purpose of regulating an industry, sometimes leaving defendant-manufacturers with little choice but to acquiesce (through

Process 273-75 (1980) (arguing that the nonjudicial branches of government should be left alone to work out their own differences), and Patricia L. Bellia, Executive Power in Youngstown's Shadows, 19 Const. Comment. 87, 91 (2002) (asserting that "the lessons that the case . . . offers . . . are less clear and less helpful than is often believed").

${ }^{266}$ See Rebecca L. Brown, Separated Powers and Ordered Liberty, 139 U. PA. L. Rev. 1513, 1523 (1991). For scholarly analyses of separation of powers typically characterized as "formalist," see generally Martin H. Redish, The Constitution as Political Structure (1995), Steven G. Calabresi \& Kevin H. Rhodes, The Structural Constitution: Unitary Executive, Plural Judiciary, 105 Harv. L. Rev. 1153 (1992), and Stephen L. Carter, Constitutional Improprieties: Reflection on Mistretta, Morrison, and Administrative Government, 57 U. CHI. L. REv. 357, 364-76 (1990). See also Bowsher v. Synar, 478 U.S. 714, 734 (1986), and INS v. Chadha, 462 U.S. 919, 959 (1983), for instances in which the Court applied formalist reasoning to declare unconstitutional the line item veto and the legislative veto, respectively.

${ }^{267}$ Youngstown, 343 U.S. at 582, 588-89.

${ }^{268} I d$. at 585-89.

${ }^{269} \mathrm{Id}$. at 586

270 See infra notes 271-274 and accompanying text.

271 See, e.g., R.I. Gen. Laws § 42-9-6 (1996).

272 See supra notes $127-215$ and accompanying text. 
a consent decree) in the attorney general's regulatory scheme.273 This appropriation of regulatory powers that state constitutions have delegated to the legislative branch suggests that the attorney general, as a member of the executive branch, violates separation of powers principles as Justice Black and other formalists conceive them. ${ }^{274}$

The alternative to the formalist approach to separation of powers is the so-called "functionalist" approach. ${ }^{275}$ Functionalism is a less rulebound, more policy-oriented approach to separation of powers that seeks an appropriate balance of power among the three coordinate branches. ${ }^{276}$ The concurring opinion of Justice Jackson in Youngstown follows a functionalist approach and, for decades, has been regarded as a starting point for assessing the legitimacy of the exercise of executive power. ${ }^{277}$ According to Justice Jackson, the President's power under the Constitution is greatest when Congress has authorized his actions, either expressly or impliedly. ${ }^{278}$ In this situation, his actions are justified by the combined powers constitutionally granted to the executive and legislative branches. ${ }^{279}$ Conversely, the President's power is "at its lowest ebb" when he "takes measures incompatible with the expressed or implied will of Congress," because "he can rely only upon his own constitutional powers minus any constitutional powers of Congress over the matter." ${ }^{880}$ In a middle category, Jackson's so-called "zone of twilight," the constitutional analysis becomes most murky. ${ }^{281}$ Here, the President and Congress either have concurrent authority or the allocation of powers is ill-defined. 282 According to Justice Jackson, in this sphere, "congressional inertia, indifference or quiescence may sometimes, at least as a practical matter, enable, if not invite, measures on independent presidential responsibility." ${ }^{283}$ Nevertheless, in Youngstown, Justice

273 See supra notes 127-215 and accompanying text.

274 See supra notes 265-269 and accompanying text.

275 See infra notes 276-284 and accompanying text.

${ }^{276}$ See Brown, supra note 266, at 1527-28; Magill, supra note 255, at 1142-43. Functionalist scholarly perspectives include, for example, Harold Bruff, Presidential Powers and Administrative Rulemaking, 88 YALE L.J. 451 (1979). See also Mistretta, 488 U.S. at 412, and Dames E Moore v. Regan, 453 U.S. 654, 668-69, 688 (1981), for instances in which the Court applied functionalist reasoning to uphold the Sentencing Reform Act and President Carter's executive agreement with Iran, respectively.

${ }^{277}$ Youngstown, 343 U.S. at 634-55 (Jackson, J., concurring).

${ }^{278} I d$. at $635-36$.

${ }^{279} I d$.

${ }^{280} I d$. at 637.

${ }^{281}$ See id.

282 Youngstown, 343 U.S. at 637 (Jackson, J., concurring).

${ }^{283} \mathrm{Id}$. 
Jackson concurred in the Court's judgment striking down the seizure of the steel plants even during a time of war. ${ }^{284}$

\section{Attorney General-Initiated Regulatory Products Claims and Justice Jackson's Analytical Framework}

\section{a. Regulatory Products Claims with Legislative Approval}

Under Justice Jackson's analytical framework, an attorney general who brings a claim against a manufacturer with express or implied legislative approval proceeds with the highest degree of legitimacy. ${ }^{285}$ Such actions are buttressed by the powers delegated to the attorney general in both the state constitution and in state legislation. For example, during the tobacco litigation, the Florida, Maryland, and Vermont legislatures each enacted legislation that at least implicitly authorized the parens patriae legal actions brought by their respective attorneys general. ${ }^{286}$ In these states, there is little question that the attorneys general possessed the constitutional authority to file litigation against the tobacco manufacturers, even if the attorney general's intent was to impose a new regulatory regime, which, in fact, is what transpired. ${ }^{287}$

\section{b. Regulatory Products Claims in the Face of Legislative Disapproval}

Justice Jackson's opinion makes it clear that a state legislature has the constitutional power to prevent the attorney general from filing a parens patriae action against either the manufacturer of a specific product or the manufacturers of all products. ${ }^{288}$ For example, during the cycle of litigation against firearm manufacturers, a number of state legislatures prohibited the filing of such actions by the state attorney general. ${ }^{289}$

284 See id. at 638-40, 654-55.

285 See id. at 635-36.

${ }^{286}$ See Fla. Stat. Ann. § 409.910 (West 2005 \& Supp. 2008); Md. Code Ann., Health-Gen. § 15-120(a) (LexisNexis 2005); Vt. Stat. AnN. tit. 33, § 1904 (2001 \& Supp. 2007).

287 See generally MSA, supra note 3.

288 See Youngstown, 343 U.S. at 637 (Jackson, J., concurring).

${ }^{289}$ See, e.g., Fla. Stat. Ann. § 790.331(2) (West 2007) (prohibiting such actions by the state, its agencies or instrumentalities, or localities); IdAHo CodE AnN. § 5-247 (2004) (prohibiting the state or any other governmental unit from bringing such a suit unless approved in advance by the legislature); Tex. Civ. Prac. \& Rem. Code Ann. § 128.001(c) (Vernon 2005) (prohibiting the filing of such a suit unless approved in advance by the legislature). 
Even in the absence of legislation explicitly prohibiting parens patriae regulatory claims by the attorney general, the legislative response to social problems such as childhood lead poisoning or tobacco-related illnesses may implicitly signal a rejection of the approach the attorney general seeks to implement in the product regulatory litigation. Consider, for example, the situation in Rhode Island, where the state legislature had enacted a comprehensive regulatory scheme designed to prevent childhood lead poisoning by placing the burden of eliminating lead-paint hazards on property owners and mandating that they undertake specified measures to render residential properties "lead-safe." ${ }^{290}$ Despite this, the state attorney general filed a parens patriae regulatory action seeking to hold manufacturers of lead pigment, not property owners, financially responsible, and imposing more demanding standards for remediation of lead-based paint hazards. ${ }^{291}$ As previously noted, the Rhode Island Supreme Court appropriately concluded that the state legislature's statutory schemes "recognized that landlords . . . are responsible for maintaining their premises and ensuring that the premises are leadsafe." ${ }^{292}$ In this situation, the legislature had implicitly-but quite clearly-rejected the fundamental goals of the Attorney General's parens patriae action seeking to hold product manufacturers' liable.

Similarly, in 2007, in In re Lead Paint Litigation, the New Jersey Supreme Court quite correctly relied heavily on the legislature's prior enactment of statutes placing the responsibility for lead-based paint abatement on property owners when it dismissed actions filed by municipalities against paint manufacturers. ${ }^{293}$ Under Justice Jackson's analysis, similar reasoning justifies dismissal of parens patriae litigation against manufacturers of other products, such as cigarettes, firearms, and OxyContin, where these industries are already heavily regulated by state and federal legislatures and by the administrative agencies specifically authorized to regulate such products. ${ }^{294}$

${ }^{290}$ See R.I. GEN. Laws $\$ \S 23-24.6-1$ to 23-24.6-27 (2001 \& Supp. 2007). The Rhode Island General Assembly enacted this regulatory scheme in 2002, yet the Rhode Island Attorney General continued the litigation against manufacturers of lead pigment. See 2002 R.I. Pub. Laws 875-910.

291 See supra notes 85-110 and accompanying text.

292 Lead Indus. Ass'n IV, 951 A.2d at 457-58.

${ }^{293} 924$ A.2d 484, 494 (N.J. 2007).

${ }^{294}$ Michael DeBow, Professor, Roundtable: State Attorney General Litigation: Regulation Through Litigation and the Separation of Powers, in Symposium, Tort Liability, The Structural Constitution, and The States, 31 Seton Hall L. Rev. 617, 617 (2001). Professor DeBow stated: 


\section{c. Regulatory Products Claims and Legislative Silence}

Whether the attorney general is authorized to act alone to initiate a regulatory civil action in the absence of either legislative approval or disapproval-expressed either explicitly or impliedly-is more difficult under Justice Jackson's analysis. ${ }^{295}$ If the legislature has been truly silent, as contrasted with the situation where the legislature merely has failed to respond with the aggressive stance preferred by public interest advocates, the resolution of this question is a difficult one and is informed by one's evaluation of the respective institutional competencies and fairness of the legislature and the office of the attorney general. These matters are considered more fully below. ${ }^{296}$

Public interest advocates and mass products liability plaintiffs' attorneys argue that state attorneys general are justified in acting on their own to sue tobacco and lead paint manufacturers because the state legislatures have failed to regulate those industries. ${ }^{297}$ They further argue that if a legislature believes that the attorney general is impinging on its authority, it can always enact legislation preventing such litigation, either generally or against a specific industry. This latter argument is suggested by the U.S. Supreme Court's reasoning in 1981 in Dames $\mathcal{E}^{\circ}$ Moore v. Regan, which held that Congress had implicitly approved the practices followed by U.S. presidents in settling claims between U.S. citizens and hostile nations, despite the lack of explicit statutory authority. ${ }^{298}$ The situation in Dames $\mathcal{E} \mathcal{F}$ Moore, however, involved more than legislative acquiescence inferred from inaction. ${ }^{299}$ There, Congress had repeatedly passed related legislation, "thus demonstrating Congress' continuing acceptance of the President's claim settlement authority.",300 In other words, the situation in Dames $\mathcal{E} \mathcal{F}$ Moore is more like those states

Let me just remind everybody that every state legislature has already enacted ... regulations on cigarettes. It is not a question of whether the legislature will fail to do anything, so that, unless you have an activist attorney general, there will be no legal policy here. It is a question of how much legal policy you want.

Id.

295 See Youngstown, 343 U.S. at 637 (Jackson, J., concurring).

296 See infra notes 308-318 and accompanying text.

${ }^{297}$ See, e.g., Coale, supra note 1, at 64 ("What has happened is that the legislatures . . . failed to regulate tobacco and they failed regarding guns. The polling data is overwhelming: Congress is not doing its job .. . . [L] [ awyers are taking up the slack.").

${ }^{298} 453$ U.S. at 679-82 (upholding President Carter's executive order suspending judicially enforced claims against Iranian interests).

${ }^{299}$ See id.

${ }^{300} I d$. at 681 . 
that passed statutes facilitating parens patriae against the tobacco companies than like state legislatures that have merely failed to act. ${ }^{301}$

It is widely accepted that the legislature's failure to act does not necessarily indicate its opposition to a proposed piece of legislation. ${ }^{302}$ Hence, the legislature's failure to stop parens patriae litigation should not be construed as acquiescence in such litigation. It is far easier to kill a legislative proposal than it is to enact it. If the attorney general indicates an intention to file a regulatory action against product manufacturers, the legislature, to stop the litigation, must undertake a difficult process that usually requires action by two houses of the legislature, the signature of the governor, and the time and energy required to accomplish these steps during an often crowded and busy legislative session. ${ }^{303}$ Adding to the legislature's challenge is the fact that often the governor and the majority in each legislative chamber are not of the same political party.

Further, in some instances, any legislative attempt to prevent parens patriae litigation against product manufacturers by the attorney general may not be legally effective because legislation is almost inevitably prospective in nature, and the common law generally operates retroactively. Consider the current situation in the State of Ohio. ${ }^{304} \mathrm{In}$ December 2006, the Ohio General Assembly passed legislation making public nuisance actions against product manufacturers subject to the requirements of the Ohio Product Liability Act, which essentially eliminated public nuisance as a separate claim. ${ }^{305}$ Despite this enactment, in April 2007, the Ohio Attorney General filed a parens patriae public nuisance action against manufacturers of lead-based paint and lead pigment. ${ }^{306}$ Yet to be decided is whether the legislation applies to harms caused by the defendants' conduct occurring prior to its pas-

\footnotetext{
${ }^{301}$ See id.

302 See, e.g., Henry M. Hart \& Albert M. Sacks, The Legal Process: Basic Problems in the Making and Application of Law 1358-60 (William N. Eskridge \& Philip P. Frickey eds., 1994); TRIBE, supra note 259, at 204-05 ("When the array of powers held by the executive, the judiciary, or the states with respect to a given matter can be transformed only by congressional approval or disapproval, then it is essential that such approval or disapproval take the form of legislation made through [the formal constitutional procedures for passing laws].”).

303 See, e.g., R.I. Const. art. VI, § 2; id. art. IX, § 14.

${ }^{304}$ See infra notes 305-307 and accompanying text.

${ }^{305}$ Ohio Rev. Code AnN. $\$ \S 2307.71$ to .80 (LexisNexis Supp. 2007).

${ }^{306}$ See generally Complaint, State v. Sherwin-Williams Co., No. 07 CV 004587 (Ohio Ct. Com. Pl. Apr. 2, 2007), available at http://www.bricker.com/legalservices/industry/manufacturing/nuisance/danncomplaint.pdf.
} 
sage ${ }^{307}$ Regardless of how this retroactivity issue ultimately is resolved, the respective actions of the Ohio legislature and attorney general illustrate the difficulties with assuming that a state legislature can always enact legislation to prevent the attorney general from filing a regulatory lawsuit establishing new state policy.

\section{Respective Institutional Competencies of the Attorney General and} the Legislature

In assessing whether the attorney general should be allowed to file parens patriae litigation designed to create a new product-regulatory framework, some courts are likely to consider the respective abilities of the attorney general and the legislature to address the difficult social problems resulting from the use of the targeted products (e.g., tobacco and lead pigment), as well as their likely biases in doing so. The real issue with such litigation often is not that the legislature has failed to regulate a product and its distribution, but rather that the extent or type of legislative or administrative regulation is not deemed optimal by the state attorney general. Attorneys general and their political allies within the public interest community and the plaintiffs' mass products torts bar recognize, as the late Gary Schwartz noted more than a decade ago, that, generally speaking, manufacturers are better able to influence state legislatures through lobbying and campaign fundraising than are consumers. ${ }^{308}$

At the same time, the deliberative legislative process, with its assortment of checks and balances, either constitutionally mandated or arising from legislative tradition, offers comparative institutional advantages over the attorney general's process of deciding whether to

${ }^{307}$ There are strong arguments suggesting that the public nuisance legislation does apply to the action filed by the attorney general. For one thing, any action seeking abatement of a public nuisance or recovery of costs of the abatement of public nuisance by its nature is an action for prospective injunctive relief. See Landgraf v. USI Film Prods., 511 U.S. 244, 273 (1994) ("When the intervening statute authorizes or affects the propriety of prospective relief, application of the new provision is not retroactive.”); Am. Steel Foundries v. Tri-City Cent. Trades Council, 257 U.S. 184, 201 (1921) (holding that the propriety of injunctive relief was governed by statutory provisions enacted while the case was pending on appeal). Second, because the Ohio legislation amended the existing products liability statutory framework, it arguably merely clarified existing legislation. See supra note 305. Clarifying statutory amendments do apply retrospectively. See Wilson v. AC\&S, Inc., 864 N.E.2d 682, 702 (Ohio Ct. App. 2006), appeal dismissed, 864 N.E.2d 645 (Ohio 2007) (holding that 2004 asbestos reform legislation applied retroactively).

${ }^{308}$ See Gary T. Schwartz, Considering the Proper Federal Role in American Tort Law, 38 ARIz. L. Rev. 917, 936-37 (1996); see also Neil Komesar, Imperfect Alternatives 192-95 (1995). 
regulate a given industry or a specific manufacturer through statesponsored litigation. ${ }^{309}$ As Jim Henderson recently concluded, "[I]t is commonly understood that, in a representative democracy, macroeconomic regulation is accomplished most appropriately by elected officials and their lawful delegates." ${ }^{310}$ The legislative process provides, theoretically and-to a greater or lesser extent-realistically, an opportunity for all parties to be heard and for their experts to testify. In contrast to the attorney general's decisionmaking, this process is a comparatively public one.

Taxing and spending also traditionally are regarded as powers within the legislative domain. ${ }^{311}$ Yet parens patriae litigation results in the equivalent of new taxes (e.g., the widespread increases in cigarette prices needed to fund the tobacco companies' payments under the MSA). The Rhode Island trial court's judgment against pigment manufacturers, until overturned on appeal, would have resulted in the spending of hundreds of millions of dollars collected by the state-all without the safeguards of the established appropriation process. ${ }^{312} \mathrm{In}$ short, attorney general-sponsored litigation intrudes upon legislative taxing and spending powers, as well as upon the regulatory functions of the legislature and the administrative agencies it specifically authorizes to implement its regulatory vision.

The type of decision-making process required to solve, or at least ameliorate, complex social problems does not easily fit within either the liability phase or the remedial phase of the judicial process. Recall the extremely vague and ill-defined boundaries of public nuisance and other torts typically employed in parens patriae actions against

${ }^{309}$ James A. Henderson, The Lawlessness of Aggregative Torts, 34 Hofstra L. REv. 329, $338(2005)$

${ }^{310} \mathrm{Id}$.

311 See, e.g., U.S. Const. art. I, § 8, cl. 1.

312 See generally АватEment Plan, supra note 94. My argument is obviously different from the contention of the defendant-manufacturers in the Rhode Island pigment litigation that "contingent fee agreements between the Attorney General and private counsel are violative of Rhode Island law because . . . such agreements are tantamount to an unlawful appropriation of state funds." See Lead Indus. Ass'n IV, 951 A.2d at 477-78. The Rhode Island Supreme Court rejected the argument because it found that "a successful contingent fee attorney has an equitable lien on any recovered damages in accordance with the term of the fee agreement." Id. at 478. The court never reached the issue analyzed here, viz., whether the trial court has directed the expenditure of the remaining balance of any proceeds of the litigation-the so-called "costs of abatement" - without legislative involvement. See generally $i d$. The process of collecting billions of dollars from defendantmanufacturers and spending them to remediate statewide housing and public health problems arguably clashes with the constitutional allocation of taxing and spending powers to the legislature. See R.I. Const. art. VI, § 2. 
products manufacturers. ${ }^{313}$ In order for the judicial process to work as intended, Henderson argues:

[T] he applicable legal rules governing a controversy must be specific enough to arrange the constituent elements into linear chains of logic so that each element may be considered more or less in isolation from the others and resolved, even if sometimes only tentatively, before moving on to the next. Only when the rules of decision are sufficiently specific to support these logical structures can each party take the judge or jury through the elements of the case to the conclusion indicated by that party's positions on the relevant facts and law. ${ }^{314}$

The limitations of judicial competency become even more apparent when courts enter the remedial phase of public products litigation intended to solve a complex public health crisis. ${ }^{315}$ For example, in the litigation brought by the State of Rhode Island against lead pigment manufacturers, the jury found that "the "cumulative presence of lead pigment in paints and coatings on buildings throughout the State . . .' constituted a public nuisance," and that the defendants should be ordered to abate the public nuisance. ${ }^{316}$ The defendants argued that because they did "not have access to the premises of homeowners, they [could not] implement any abatement remedy." 317 As previously noted, the trial court acknowledged both its own lack of public health expertise and the difficulty of using the traditional judicial process to solve polycentric problems. ${ }^{318}$

One further factor suggests that the attorney general is less likely than the legislature and its authorized administrative agencies to identify cost effective solutions to public health problems and to fairly assess which parties should bear the responsibility to remedy them. ${ }^{319}$ Public products litigation inherently seeks funds, whether characterized as damages or as "the costs of abatement," from defendants. ${ }^{320}$ It is in the best interests of the attorney general-and it is especially in the best interests of the contingent fee-financed private counsel re-

313 See supra notes 186-203 and accompanying text.

${ }^{314}$ Henderson, supra note 310 , at 339 .

315 See supra notes 15-20 and accompanying text.

${ }^{316}$ Lead Indus. Ass'n III, 2007 R.I. Super. LEXIS 32, at *1 (quoting Question 1 of the Jury Verdict Form).

${ }^{317} I d$. at $* 291$.

${ }^{318}$ See supra notes 15-20 and accompanying text.

319 See infra notes 320-322 and accompanying text.

320 See, e.g., Lead Indus. Ass'n I, 2001 R.I. Super. LEXIS 37, at*3 n.3. 
tained by the attorney general-to characterize a well-heeled defendant as the principal cause of a public health problem and as the source of its solution. Further, the interests of contingent fee-financed private counsel conflict with the goals of finding cost-effective solutions and maintaining state fiscal responsibility.

In summary, public products litigation represents a major shift in regulatory power from the legislative branch and administrative agencies to the state attorney general in a manner unforeseeable even fifteen years ago. ${ }^{321}$ Under traditional notions of allocations of powers within our tripartite systems, these assertions of power by the attorney general, when acting without explicit or implicit legislative approval, appear to be out of line with the constitutionally provided allocation of powers among the coordinate branches. ${ }^{322}$

\section{The Distortion of Public Policy Resulting from Public Hiring of Private Contingent Fee Attorneys}

In most but not all instances of parens patriae litigation against product manufacturers, state attorneys general or municipal officials have hired private attorneys, almost inevitably chosen from a small cadre of sophisticated plaintiffs' mass products litigation firms, to prosecute the litigation for them. ${ }^{323}$ For example, one of the firms that provided leadership for the tobacco litigation now litigates against lead pigment manufacturers. ${ }^{324}$

These arrangements between state attorneys general and plaintiffs' mass tort firms provide that outside counsel will be paid on a contingent fee basis. ${ }^{325}$ In other words, the retained attorneys receive a percentage of the state or local government's recovery as compensation for their services. Without the use of contingent fee arrangements, most states would not be able to match the quantity and quality of legal resources committed to mass products litigation by defendant-manufacturers. ${ }^{326}$ For example, the State of Rhode Island's brief in opposition to a motion challenging its employment of outside counsel paid on

321 See supra notes 225-320 and accompanying text.

322 See supra notes 225-320 and accompanying text.

${ }^{323}$ A few state attorneys general's offices, notably California's, make it a practice not to hire outside counsel on a contingent fee basis.

${ }^{324}$ See, e.g., State v. Lead Indus. Ass'n (Lead Indus. Ass'n IV), 951 A.2d 428, 469 (R.I. 2008).

${ }^{325}$ Brief of Respondent, the State of Rhode Island at 3, State v. Lead Indus. Ass'n, 898 A.2d 1234 (R.I. 2006) (No 2004-63-M.P.), 2005 RI S. Ct. Briefs LEXIS 12, at*11.

${ }^{326} \mathrm{Id}$. 
a contingent fee basis noted that the roster of counsel in the lead pigment litigation included twenty-nine local attorneys and ninety-two outof-state attorneys representing the defendant manufacturers. ${ }^{327}$ At the same time, the entire Government Litigation Unit of the Civil Division of the Rhode Island Attorney General's Office consisted of thirteen attorneys, of whom three were assigned to the case. ${ }^{328}$

The hiring of plaintiffs' firms by state and local governments on a contingent fee basis has been highly controversial during the past decade. ${ }^{329}$ Before the initiation of the tobacco litigation, states entered into fee agreements that resulted in the privately retained tobacco attorneys being entitled to fees that were estimated to exceed $\$ 25$ billion. ${ }^{330}$ Not surprisingly, state governments and voters sometimes balked at the payment of these fees. ${ }^{331}$

In later cycles of litigation against other industries, defendantmanufacturers have challenged the legality of government officials retaining private attorneys on a contingent fee basis with mixed results. ${ }^{332}$ In 2008, in State v. Lead Industries Ass'n, the Rhode Island Supreme Court rejected such a challenge and concluded that "such contractual relationships may well, in some circumstances, lead to results that will be beneficial to society-results which otherwise might not have been attainable." 333 At the same time, the court indicated that the Attorney General must retain "absolute and total control over all critical decision-making" when private counsel are retained on a contingent fee basis. ${ }^{334}$ In contrast, President George W. Bush recently issued an executive order prohibiting federal agencies from entering into contingent fee contracts with outside counsel in virtually all cases. ${ }^{335}$

\footnotetext{
${ }^{327} I d$.

${ }^{328} I d$.

329 See infra notes 330-338 and accompanying text.

${ }^{330}$ See Lester Brickman, Effective Hourly Rates of Contingency-Fee Lawyers: Competing Data and Non-Competitive Fees, 81 WASH. U. L.Q. 653, 720-21 (2003).

${ }^{331}$ See, e.g., Brown \& Williamson Tobacco Corp. v. Chesley, 749 N.Y.S.2d 842, 850 (Sup. Ct. 2002) (overturning arbitration determination of $\$ 1.25$ billion dollars in tobacco lawyers' fees); Minn. High Court Asked to Rule on Tobacco Fee, Mealey's Litig. Rep.: Tobacco 5 (Feb. 3, 2000) (describing a challenge to a $\$ 440.8$ million fee award for attorneys representing the State of Minnesota in tobacco litigation).

332 See, e.g., Lead Indus. Ass'n IV, 951 A.2d at 469.

${ }^{333}$ Id. at 475-76; accord County of Santa Clara v. Superior Court, 74 Cal. Rptr. 3d 842, 853 (Ct. App. 2008) (holding that public entities are not barred from "engaging private counsel under a contingent fee arrangement . . . so long as the public entities' in-house counsel retain control over all decisionmaking”), review granted, No. S163681, 2008 Cal. LEXIS 9073 (Cal. July 23, 2008).

${ }^{334}$ Lead Indus. Ass'n IV, 951 A.2d at 475-76.

${ }^{335}$ See Exec. Order No. 13,433, 72 Fed. Reg. 28,441 (May 16, 2007).
} 
The most dangerous aspect of the attorney general's use of contingent fee attorneys-and one not yet acknowledged by any courtflows naturally from the allocation of powers analysis previously presented. ${ }^{336}$ The government's selection of a course of action to solve highly complex public health problems probably is inherently influenced by the possible presence of a "deep pocket" manufacturing defendant. Mass products plaintiffs' firms routinely lobby state attorneys general and urge them to litigate against one industry or another. The evolving partnership between contingent fee counsel and state attorneys general thus determines which public health problems receive public attention. Allergies to mold, dust, and other substances, particularly among children from low-income backgrounds, are far more pervasive problems than childhood lead poisoning, ${ }^{337}$ yet these public health issues are unlikely to be addressed because the funds for prevention must come from tax dollars appropriated by the legislature and not from "out-of-state" corporations with substantial resources. ${ }^{338}$

The possibility of identifying defendants who have significant resources or applicable insurance coverage probably also influences state governments' decisions regarding how a particular public health problem should be addressed and whom should be expected to pay for the remedial measures. For example, the existence of the wellheeled manufacturer of OxyContin probably distorted a neutral public policy analysis, which might have shown that ending OxyContin

336 See supra notes 244-322 and accompanying text.

${ }^{337}$ According to the Centers for Disease Control and Prevention (the "CDC"), by 1996, asthma affected 6.2 percent of all American children, resulting in 14 million lost days of school and 266 deaths in 1996, and making it the third-leading cause of hospitalization among children. See Ctrs. for Disease Control \& Prevention, Asthma's Impact on Children and Adolescents, http://www.cdc.gov/asthma/children.htm (last visited June 22, 2008). In comparison, the CDC estimates that during the period from 1999 to 2000, 2.2 percent of American children ages one to five years had elevated blood lead levels deemed to be of concern to the CDC. Pamela A. Meyer, et al., Surveillance for Elevated Blood Lead Levels Among Children-United States, 1997-2001, in 52 Morbidity \& Mortality Wkly. Rep. 1, 11 tbl.1 (CDC Surveillance Summaries No. SS-10, Sept. 12, 2003), available at http:// www.cdc.gov/mmwr/PDF/ss/ss5210.pdf. The handful of tragic deaths of children from lead during recent decades resulted from ingestion of metallic toys and trinkets, not leadbased paint. See, e.g., Death of a Child After Ingestion of a Metallic Charm-Minnesota, 2006, in 55 Morbidity \& Mortality Wkly. Rep. 340, 340-41 (CDC Weekly Report No. 12, Mar. 31, 2006), available at http://www.cdc.gov/mmwr/PDF/wk/mm5512.pdf.

${ }^{338}$ The CDC has launched the Healthy Homes Initiative to "[b]roaden the scope of single-issue public health programs, such as childhood lead poisoning prevention . . . to address multiple housing deficiencies that affect health and safety." See Ctrs. for Disease Control \& Prevention, Healthy Homes Initiative, http://www.cdc.gov/healthyplaces/ healthyhomes.htm (last visited June 22, 2008). 
abuse in West Virginia should focus on disciplining physicians who substantially over-prescribed the painkiller. The perceived deep pockets of former lead pigment and lead paint manufacturers have led Rhode Island, Ohio, and a number of municipalities to conclude that manufacturers, and not property owners, should bear responsibility for eliminating lead-based paint hazards. Despite prior state legislative $^{339}$ and federal administrative ${ }^{340}$ determinations that the appropriate response to lead-based paint hazards is to implement costeffective, so-called interim controls, the financial interests of contingent fee attorneys favor advocating total abatement as the appropriate level of regulation at much greater cost. The greater the recovery or settlement proceeds paid by defendant-manufacturers, the larger the fee will be for plaintiffs' counsel retained on a contingent fee basis.

Not surprisingly, the plaintiffs' lawyers hired by state attorneys general to litigate the case against lead pigment manufacturers often have been significant contributors to the political campaigns of the attorneys general. ${ }^{341}$ Lobbying and campaign contributions, of course, are not unheard of in state legislatures. The legislature, however, is understood to be a political institution responding to clashing perceptions of the popular will and, probably to an unfortunate extent, campaign contributors. Influencing the state attorney general's decision whether to file litigation on behalf of the state through persistent lobbying arguably is less consistent with traditional conceptions of that public office.

In any event, it seems safe to assume that the locus of policymaking has shifted away from the popularly elected legislature and the administrative agencies it creates to implement its regulatory vision. Power has devolved to the attorney general, an official whose powers today greatly exceed those traditionally envisioned for that position. More importantly, many attorneys general exercise their in-

${ }^{339}$ See, e.g., Md. Code AnN., Envir. § 6-815 (LexisNexis 2008); R.I. Gen. Laws § 2324.6-4(15) (2001 \& Supp. 2007).

${ }^{340}$ See, e.g., 42 U.S.C. $§ \$ 4851-4856$ (2000); 24 C.F.R. $§ ~ 35.100-35.175$ (2007); Requirements for Notification, Evaluation and Reduction of Lead-Based Paint Hazards in Federally Owned Residential Property and Housing Receiving Federal Assistance, 64 Fed. Reg. 50,140, 50,142 (Sept. 15, 1999) (codified in scattered sections of 24 C.F.R.).

${ }^{341}$ See, e.g., Rhode Island Board of Elections Contribution Reporting, http://www.ri campaignfinance.com/RIPublic/Contributions.aspx (enter "McConnell" under Donor Last Name and "John" under Donor First Name) (last visited June 23, 2008) (showing contributions of John J. McConnell, Jr., one of the state's privately retained trial counsel in the Rhode Island litigation against pigment manufacturers, to "Friends of Patrick Lynch," the campaign fund of the current Rhode Island Attorney General). 
creased policy discretion by focusing the blame for creating costly social problems on those manufacturers who possess considerable resources, in order to avoid politically costly tax increases. Not coincidentally, some political observers claim that the abbreviation for the attorney general, "AG," stands for "aspiring governor." ${ }^{342}$ Plaintiffs' firms that promise millions or billions of dollars of new resources for the state without any financial obligation on its part augment this distortion of the attorney general's decision-making process. Firms promising such fortuitous outcomes, of course, stand to enrich themselves in the process.

\section{Conclusion}

Despite the success of attorney general-driven parens patriae litigation in achieving the largest-ever settlement of civil claims in the tobacco litigation, to a large extent, public products litigation has escaped judicial scrutiny precisely because such claims have settled. ${ }^{343}$ In the few instances when these claims have been judicially testednotably in the recent litigation against lead paint pigment manufacturers in Rhode Island-more often than not manufacturers prevail, usually on the grounds that public nuisance and other vague torts cannot be expanded beyond traditional doctrinal boundaries.

Lurking in the background of these opinions appears to be a more significant judicial concern: a nascent understanding that the attorney general's filing of parens patriae litigation against manufacturers of products already regulated through the legislative process distorts our constitutional structure. ${ }^{344}$ Attorneys general, many of whom became lawyers during an era that revered judicial activism, should not be faulted for seeking to use the full authority of their offices (and perhaps even more) to try to solve critical social problems. The notion of benefiting public health and public safety without spending tax revenues is a beguiling one, relentlessly espoused by a handful of national plaintiffs' mass torts law firms that stand to profit handsomely. This idea no doubt appeals to an electorate that often

${ }^{342}$ Brooke A. Masters, States Flex Prosecutorial Muscle, WAsh. Post, Jan. 12, 2005, at A1.

${ }^{343}$ In the case of claims against firearm manufacturers, Congress, for all intents and purposes, ended the litigation cycle by enacting the Protection of Lawful Commerce in

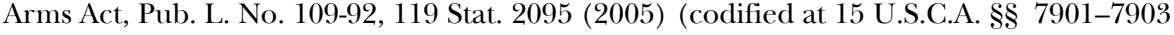
(West Supp. 2007)).

${ }^{344}$ See In re Lead Paint Litig., 924 A.2d 484, 502 n.8, 505 (N.J. 2007) (concluding that there is no public nuisance claim against manufacturers of lead paint due in large part to the legislature's enactment of an alternative scheme to address childhood lead poisoning). 
seems to be wealthy enough to oppose taxation in any form, but populist enough to want to soak wealthy "out-of-state" corporations.

As imperfect as the functioning of state legislatures in reality may be, the attorney general's appropriate role within the constitutional framework is not to replace the legislatively enacted provisions regulating products with a regulatory scheme, whether resulting from settlement or judicial decree, which implements his or her own vision of social engineering. Nor will public policymaking be improved by a process that prioritizes regulatory goals depending on whether corporations with perceived deep pockets can be blamed for causing a particular public health problem.

In recent years, courts have checked the growing aggrandizement of executive power elsewhere within our constitutional structure. ${ }^{345}$ So far, the litigation filed by state attorneys general and mass products plaintiffs' law firms to impose more stringent regulation on manufacturers has slipped below the radar screen. Yet supplanting the legislatively enacted regulatory schemes for cigarettes and childhood lead poisoning, without so much as the introduction of a bill or a hearing, is not trivial. Nor is it democratic.

${ }^{345}$ See, e.g., Massachusetts v. EPA, 127 S. Ct. 1438, 1462, 1463 (2007) (finding that the EPA had refused to comply with a "clear statutory command" in declining to set standards for greenhouse gas emissions and stating that the President's broad authority "does not extend to the refusal to execute domestic laws"); Hamdan v. Rumsfeld, 548 U.S. 557, 593 \& n.23 (2006) (concluding that the President did not have the authority to establish military tribunals that disregarded congressional limits placed on the exercise of his war powers). 
